\title{
The metabolic syndrome of $\omega 3$-depleted rats. I. Liver data
}

\author{
WILLY J. MALAISSE ${ }^{1}$, NURDAN BULUR ${ }^{1}$, YING ZHANG ${ }^{1}$, MIRJAM HACQUEBARD ${ }^{2}$, \\ LAURENCE PORTOIS $^{2}$, ABDULLAH SENER ${ }^{1}$ and YVON A. CARPENTIER ${ }^{2}$
}

Laboratories of ${ }^{1}$ Experimental Hormonology, ${ }^{2}$ Experimental Surgery, Université Libre de Bruxelles, Brussels, Belgium

Received March 19, 2009; Accepted April 24, 2009

\section{DOI: 10.3892/ijmm_00000214}

\begin{abstract}
Second-generation rats depleted in long-chain polyunsaturated $\omega 3$ fatty acids were recently proposed as a novel animal model for the metabolic syndrome. In the present study, a dietary deprivation of $\omega 3$ acids for 3-7 months was found sufficient to provoke in 6-week-old normal rats the same alteration of the fatty acid content and profile of liver phospholipids and triglycerides as that otherwise prevailing in the second-generation $\omega 3$-depleted rats, with emphasis on a severe decrease in their $\omega 3$ fatty acid content, alterations in the relative contribution of and ratio between selected long-chain polyunsaturated $\omega 6$ fatty acids, saturated and monodesaturated fatty acids and precursors of nervonic acid, and liver steatosis. When the $\omega 3$-depleted rats were exposed, after the first 7 months of the present experiments and for 2-4 weeks to a diet supplemented with $5 \%(\mathrm{w} / \mathrm{w})$ flaxseed oil, most of these hepatic variables returned towards or beyond control values. In both the $\omega 3$-depleted rats and control animals, however, the eventual exposure to the flaxseed oilenriched diet failed to suppress liver steatosis and, on the contrary, provoked a further increase in liver triglyceride content. It is proposed, therefore, that the present approach represents a simple and realistic animal model to study the consequences of $\omega 3$-depletion. Moreover, the results suggest that to oppose such consequences, e.g. liver steatosis, it may be necessary to combine the dietary supply of $\omega 3$ acids with a suitable control of food intake, in both qualitative and quantitative terms.
\end{abstract}

\section{Introduction}

Recent publications have drawn attention to the fact that second-generation rats depleted in long-chain polyunsaturated $\omega 3$ fatty acids present several features of the metabolic syndrome, including visceral obesity, liver steatosis, insulin

Correspondence to: Professor Willy J. Malaisse, Laboratory of Experimental Hormonology, Université Libre de Bruxelles, 808 Route de Lennik, B-1070 Brussels, Belgium

E-mail:malaisse@ulb.ac.be

Key words: $\omega 3$-depleted rats, liver phospholipids, liver triglycerides, fatty acid pattern resistance, hypertension and consequent cardiac hypertrophy (1-6). The major aim of the present experiments was to find out whether a comparable situation prevails in rats exposed to a dietary manipulation more likely to simulate the conditions presently often leading to a depletion of the $\omega 3$ fatty acids in Western populations. For such a purpose, normal female 6-week-old rats were exposed for 3 and 7 months to either a control diet or an $\omega 3$-depleted diet. Thereafter, the $\omega 3$-deficient rats $(\omega 3 \mathrm{D}$ rats) were given access for 2 and 4-5 weeks to the same $\omega 3$-deficient diet now enriched with $5 \%(\mathrm{w} / \mathrm{w})$ flaxseed oil. For purpose of comparison, the control rats were also exposed from day 271 to 302 after birth to their control diet enriched with $5 \%(\mathrm{w} / \mathrm{w})$ of either soybean or flaxseed oil.

The present first report deals mainly with the measurements of the fatty acid content and profile of liver phospholipids and triglycerides in the eight groups of rats mentioned above. The fatty acid content and profile of lipids in other organs (brain, duodenum-jejunum, caecum, colon), as well as the time course for changes in body weight and information on parametrial fat weight, plasma glucose and insulin concentrations will be presented in further reports.

\section{Materials and methods}

Forty-eight 6-week-old female normal rats (Iffa Credo, L'Arbresle, France) were housed in groups of 6 rats each, and given access to tap water and either a control diet (AO3; SAFE, Villemoison-sur-Orge, France) or an w3-depleted diet. The lipid composition of these two diets is given in Table I. The control and $\omega 3$-depleted diet contained 5\% (w/w) lipids from soya and sunflower, respectively, the C18:3w3 weight percentage being below the limit of detection in the latter diet. Two groups of 6 control rats each and two groups of $\omega 3 \mathrm{D}$ rats each were sacrificed after 3 and 7 months of exposure to their respective diets, i.e. $97 \pm 1$ and $264 \pm 1$ days after birth. From day 271 after birth and for the next 4-5 weeks, the control rats were given access to the control diet enriched with $5 \%$ (wt/wt) soybean or flaxseed oil (Table I). Also from day 271 after birth, the $\omega 3 \mathrm{D}$ rats were given access for either 2 or 4-5 weeks to their $\omega 3$-depleted diet enriched with $5 \%$ (wt/wt) flaxseed oil (Table I).

In the Tables, the following symbols are used: $3 \mathrm{mC}$ and $7 \mathrm{mC}$ for the control rats examined 3 and 7 months after the onset of the present experiments, $3 \mathrm{mD}$ and $7 \mathrm{mD}$ for the $\omega 3 \mathrm{D}$ rats also examined 3 and 7 months after the start of the experiments, $7 \mathrm{mC} / 4 \mathrm{wS}$ and $7 \mathrm{mC} / 4 \mathrm{mF}$ for the control rats 
Table I. Fatty acid composition of diets (\%o of total fatty acid content).

\begin{tabular}{|c|c|c|c|c|c|}
\hline Oil & Soya $(5 \%)$ & Sunflower (5\%) & Soya $(10 \%)$ & $\begin{array}{l}\text { Soya }(5 \%) \\
\text { Flax }(5 \%)\end{array}$ & $\begin{array}{c}\text { Sunflower }(5 \%) \\
\text { Flax }(5 \%)\end{array}$ \\
\hline C6:0 & 0.4 & - & - & - & 0.2 \\
\hline $\mathrm{C} 8: 0$ & - & 0.3 & - & - & 0.1 \\
\hline C10:0 & - & 0.4 & - & - & 0.3 \\
\hline $\mathrm{C} 12: 0$ & 1.0 & 0.6 & 0.1 & 0.2 & 0.4 \\
\hline C14:0 & 3.0 & 2.4 & 2.0 & 1.9 & 1.5 \\
\hline C16:0 & 138.9 & 64.6 & 113.7 & 83.3 & 54.9 \\
\hline $\mathrm{C} 16: 1 \omega 7$ & 6.5 & - & - & 3.2 & 0.8 \\
\hline C18:0 & 25.8 & 37.6 & 27.2 & 26.5 & 33.3 \\
\hline 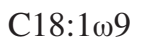 & 178.3 & 232.9 & 201.1 & 171.3 & 194.8 \\
\hline $\mathrm{C} 18: 2 \omega 6$ & 548.6 & 650.7 & 559.9 & 341.0 & 394.4 \\
\hline $\mathrm{C} 18: 3 \omega 6$ & - & - & - & - & - \\
\hline C20:0 & 2.2 & - & 3.4 & 0.8 & 0.8 \\
\hline $\mathrm{C} 18: 3 \omega 3$ & 60.2 & - & 71.6 & 351.0 & 310.3 \\
\hline 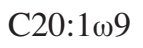 & 4.7 & - & 4.5 & 4.2 & 1.2 \\
\hline $\mathrm{C} 18: 4 \omega 3$ & 0.9 & 0.5 & 0.4 & 0.4 & - \\
\hline $\mathrm{C} 20: 2 \omega 6$ & 1.5 & 1.1 & 1.2 & 1.2 & 1.0 \\
\hline $\mathrm{C} 20: 3 \omega 6$ & 0.6 & 0.6 & 0.6 & 0.4 & 0.4 \\
\hline C22:0 & 2.0 & 5.8 & 2.7 & 1.4 & 3.2 \\
\hline $\mathrm{C} 20: 4 \omega 6$ & 1.8 & - & 0.7 & 1.1 & 0.4 \\
\hline $\mathrm{C} 22: 1 \omega 9$ & - & 0.5 & - & 1.3 & 0.5 \\
\hline $\mathrm{C} 20: 5 \omega 3$ & 6.9 & 0.4 & 3.1 & 3.0 & 0.2 \\
\hline $\mathrm{C} 24: 0$ & 0.3 & 1.7 & - & 1.1 & 1.4 \\
\hline $\mathrm{C} 22: 3 \omega 3$ & 0.4 & - & - & - & - \\
\hline $\mathrm{C} 22: 4 \omega 6$ & - & - & 0.2 & 0.2 & - \\
\hline $\mathrm{C} 22: 5 \omega 3$ & 1.1 & - & 0.8 & - & - \\
\hline $\mathrm{C} 22: 6 \omega 3$ & 15.0 & - & 6.5 & 6.5 & - \\
\hline
\end{tabular}

exposed during the last 4-5 weeks to either the soybean (S) or flaxseed (F) oil-enriched diets, and $7 \mathrm{mD} / 2 \mathrm{wF}$ and $7 \mathrm{mD} / 4 \mathrm{wF}$ for the $\omega 3 \mathrm{D}$ rats exposed for either 2 or $4-5$ weeks to the flaxseed oil-enriched diet.

The rats were eventually euthanized by carbon dioxide inhalation. Blood was punctured from the heart and a piece of liver sampled for measuring the fatty acid content and pattern of hepatic phospholipids and triglycerides. The lipids were extracted (7), separated by thin-layer chromatography (8), and their fatty acid pattern determined by gas-liquid chromatography (9).

All results are presented as means \pm SE together with either the number of individual determinations ( $\mathrm{n}$ ) or degree of freedom (df). The statistical significance of differences between mean values was assessed using Student's t-test and confirmed by variance analysis with Bonferroni post-test.

\section{Results}

Liver protein content. The liver protein content failed to differ significantly in control and $\omega 3 \mathrm{D}$ rats, whether 3 months $(\mathrm{p}>0.9)$ or 7 months $(\mathrm{p}>0.6)$ after the onset of the present experiments (Table II). It also failed to be significantly affected when the control animals ( $>0.2$ or more) or $\omega 3 \mathrm{D}$ rats ( $>0.5$ or more) were exposed for 2 to $4-5$ weeks to the diets enriched with soybean or flaxseed oil.

Liver phospholipids. Total fatty acid content. The total fatty acid content of phospholipids was significantly lower in $\omega 3 \mathrm{D}$ rats than in control animals, whether 3 months or 7 months after the onset of the present experiments (Table II). It decreased with increasing age in both the control animals $(\mathrm{p}<0.005)$ and $\omega 3 \mathrm{D}$ rats $(\mathrm{p}<0.05)$. When the control rats were exposed for 4-5 weeks to the diets enriched with soybean or flaxseed oil, the mean value for the total fatty acid content of liver phospholipids increased. Such an increase achieved statistical significance in the case of the flaxseed oil-rich diet $(\mathrm{p}<0.05)$, and even in the case of the soybean oil-rich diet $(\mathrm{p}<0.005)$ after exclusion of one abnormally low value $(13.3 \mathrm{mg} / \mathrm{g})$ recorded in the latter group of rats.

When the $\omega 3 \mathrm{D}$ rats were exposed to the $\omega 3$-enriched diet, the total fatty acid content of liver phospholipids progressively increased $(p<0.005)$ and eventually reached a mean value no more significantly different $(p>0.1)$ from that recorded at the same age in the control rats.

Long-chain polyunsaturated $\omega 3$ fatty acids. The relative weight content of long-chain polyunsaturated $\omega 3$ fatty acids was 
Table II. Protein and total fatty acid content (mg/g wet wt.) of liver phospholipids and triglycerides.

\begin{tabular}{|c|c|c|c|c|}
\hline Rats & $\begin{array}{l}\text { Protein } \\
(\mathrm{mg} / \mathrm{g})\end{array}$ & $\begin{array}{l}\text { Phospholipids } \\
(\mathrm{mg} / \mathrm{g})\end{array}$ & $\begin{array}{l}\text { Triglycerides } \\
(\mathrm{mg} / \mathrm{g})\end{array}$ & Triglycerides/Phospholipids \\
\hline $3 \mathrm{mC}$ & $241 \pm 4(6)$ & $27.9 \pm 0.9(5)$ & $2.62 \pm 0.22(6)$ & $0.090 \pm 0.011(5)$ \\
\hline $3 \mathrm{mD}$ & $241 \pm 5(6)$ & $20.5 \pm 0.6(5)^{\mathrm{e}}$ & $5.04 \pm 0.53(6)^{\mathrm{e}}$ & $0.248 \pm 0.026(5)^{\mathrm{f}}$ \\
\hline $7 \mathrm{mC}$ & $232 \pm 2(5)$ & $22.1 \pm 0.8(5)$ & $3.11 \pm 0.31(5)$ & $0.138 \pm 0.011$ \\
\hline $7 \mathrm{mD}$ & $234 \pm 4(6)$ & $18.8 \pm 0.4(6)^{\mathrm{e}}$ & $4.75 \pm 0.38(6)^{\mathrm{d}}$ & $0.247 \pm 0.024(6)^{\mathrm{e}}$ \\
\hline $7 \mathrm{mC} / 4 \mathrm{wS}$ & $240 \pm 6(6)$ & $24.0 \pm 2.1(6)$ & $5.21 \pm 0.73(6)$ & $0.215 \pm 0.021$ \\
\hline $7 \mathrm{mC} / 4 \mathrm{wF}$ & $228 \pm 9(6)$ & $25.1 \pm 0.8(6)$ & $4.80 \pm 0.71(6)$ & $0.190 \pm 0.026$ \\
\hline $7 \mathrm{mD} / 2 \mathrm{wF}$ & $239 \pm 6(6)$ & $19.5 \pm 1.0(6)$ & $6.11 \pm 0.97(6)$ & $0.298 \pm 0.038$ \\
\hline $7 \mathrm{mD} / 4 \mathrm{wF}$ & $231 \pm 9(6)$ & $23.8 \pm 0.3(6)^{\mathrm{e}}$ & $7.78 \pm 1.57(6)$ & $0.297 \pm 0.057(6)$ \\
\hline
\end{tabular}

Values are means \pm SE; nos. in parentheses indicate the no. of individual determinations for each value. The statistical indices $\left({ }^{\mathrm{a}} \mathrm{p}<0.05\right.$; $\left.{ }^{\mathrm{b}} \mathrm{p}<0.025 ;{ }^{\mathrm{c}} \mathrm{p}<0.02 ;{ }^{\mathrm{d}} \mathrm{p}<0.01 ;{ }^{\mathrm{e}} \mathrm{p}<0.005 ;{ }^{\mathrm{f}} \mathrm{p}<0.001\right)$ refer to the differences with the preceding line. The symbols for each group of rats are defined in Materials and methods.

Table III. Weight percentage of long-chain polyunsaturated $\omega 3$ fatty acids in liver phospholipids.

\begin{tabular}{|c|c|c|c|c|}
\hline Rat & $\mathrm{C} 18: 3 \omega 3$ & $\mathrm{C} 20: 5 \omega 3$ & $\mathrm{C} 22: 5 \omega 3$ & $\mathrm{C} 22: 6 \omega 3$ \\
\hline $3 \mathrm{mC}$ & $0.2 \pm 0.1(6)$ & $1.3 \pm 0.2(6)$ & $1.3 \pm 0.1(6)$ & $17.9 \pm 0.7(6)$ \\
\hline $3 \mathrm{mD}$ & $0.0 \pm 0.0(6)^{\mathrm{c}}$ & $0.0 \pm 0.0(6)^{\mathrm{f}}$ & $0.0 \pm 0.0(6)^{\mathrm{f}}$ & $4.3 \pm 0.3(6)^{f}$ \\
\hline $7 \mathrm{mC}$ & $0.2 \pm 0.0$ & $1.2 \pm 0.3(5)$ & $1.2 \pm 0.0(5)$ & $16.3 \pm 0.8(5)$ \\
\hline $7 \mathrm{mD}$ & $0.0 \pm 0.0(6)^{\mathrm{f}}$ & $0.0 \pm 0.0(6)^{\mathrm{e}}$ & $0.1 \pm 0.0(6)^{\mathrm{f}}$ & $3.5 \pm 0.2(6)^{f}$ \\
\hline $7 \mathrm{mC} / 4 \mathrm{wS}$ & $0.2 \pm 0.0(6)$ & $0.6 \pm 0.1(6)$ & $1.1 \pm 0.1(6)$ & $15.2 \pm 0.7(6)$ \\
\hline $7 \mathrm{mC} / 4 \mathrm{wF}$ & $0.9 \pm 0.1(6)^{\mathrm{f}}$ & $3.9 \pm 0.6(6)^{\mathrm{f}}$ & $2.3 \pm 0.1(6)^{f}$ & $13.9 \pm 0.7(6)$ \\
\hline $7 \mathrm{mD} / 2 \mathrm{wF}$ & $0.7 \pm 0.1(6)$ & $3.0 \pm 0.8(6)$ & $1.8 \pm 0.1(6)$ & $15.3 \pm 0.6(6)$ \\
\hline $7 \mathrm{mD} / 4 \mathrm{wF}$ & $0.7 \pm 0.1(6)$ & $3.4 \pm 0.5(6)$ & $1.8 \pm 0.2(6)$ & $15.0 \pm 1.2(6)$ \\
\hline
\end{tabular}

Same presentation as in Table II.

much lower in the liver phospholipids of $\omega 3 \mathrm{D}$ rats as compared to control animals of the same age (Table III).

When the control animals were exposed for 4-5 weeks to the flaxseed oil-rich diet, the relative weight content of all long-chain polyunsaturated $\omega 3$ fatty acids, except C22:6 $\omega 3$, became significantly higher than that found in either the control animals examined after 7 months exposure to the control diet or the control animals given access to the soybean oil-rich diet for the last 4-5 weeks before sacrifice. Except in the case of $\mathrm{C} 20: 5 \omega 3$ ( $\mathrm{p}<0.02)$, the weight percentage of longchain polyunsaturated $\omega 3$ fatty acids in liver phospholipids failed to differ significantly in the latter two groups of animals (Table III).

When the $\omega 3 \mathrm{D}$ rats were given access to the $\omega 3$-enriched diet, the relative weight content of $\mathrm{C} 18: 3 \omega 3, \mathrm{C} 20: 5 \omega 3$ and $\mathrm{C} 22: 5 \omega 3$ reached, within 2 weeks, steady-state values significantly higher $(\mathrm{p}<0.001)$ than those recorded in the control rats during the first 7 months of the present experiments. Only the relative weight of $\mathrm{C} 22: 6 \mathrm{w} 3$ in liver phospholipids remained slightly lower $(\mathrm{p}<0.05)$ in the $\omega 3 \mathrm{D}$ rats given access for $2-5$ weeks to the $\omega 3$-enriched diet $(15.1 \pm 0.6 \% ; \mathrm{n}=12)$ than in the control rats examined during the first 7 months of the present experiments $(17.1 \pm 0.6 \%$; $\mathrm{n}=11$ ).

The C20:5 $23 / \mathrm{C} 18: 3 \omega 3$ ratio was significantly lower $(\mathrm{p}<0.005)$ in the control animals fed an oil-enriched diet $(3.61 \pm 0.27 ; n=12)$ than in the control animals examined during the first 7 months of the present experiments $(5.68 \pm 0.63$; $\mathrm{n}=10$ ). Relative to the results found in the control animals exposed for 7 months to the control diet, the C22:6w3/ $\mathrm{C} 20: 5 \omega 3$ ratio was twice higher $(\mathrm{p}<0.025)$ after feeding these animals the soybean oil-enriched diet, but about four times lower $(\mathrm{p}<0.01)$ when the control rats were given access to the flaxseed oil-enriched diet. The $\mathrm{C} 22: 5 \omega 3 / \mathrm{C} 22: 6 \omega 3$ ratio was virtually identical in the control rats before and after exposure to the soybean oil-enriched diet, whilst being doubled $(\mathrm{p}<0.001)$ after exposure of the control rats to the flaxseed oil-enriched diet.

The $\mathrm{C} 20: 5 \omega 3 / \mathrm{C} 18: 3 \omega 3$ ratio in liver phospholipids failed to differ significantly $(\mathrm{p}>0.1)$ in the control animals examined during the first 7 months of the present experiments $(5.68 \pm 0.63 ; \mathrm{n}=10)$ and in the $\omega 3 \mathrm{D}$ rats given access to the $\omega 3$-enriched diet $(4.44 \pm 0.52 ; n=12)$. The $\mathrm{C} 22: 6 \omega 3 / \mathrm{C} 20: 5 \omega 3$ ratio was lower $(\mathrm{p}<0.005)$, however, in the latter rats 
Table IV. Ratio between selected long-chain polyunsaturated $\omega 3$ fatty acids in liver phospholipids.

\begin{tabular}{lccc}
\hline Rats & $\mathrm{C} 20: 5 \omega 3 / \mathrm{C} 18: 3 \omega 3$ & $\mathrm{C} 22: 6 \omega 3 / \mathrm{C} 20: 5 \omega 3$ & $\mathrm{C} 22: 5 \omega 3 / \mathrm{C} 22: 6 \omega 3\left(10^{-3}\right)$ \\
\hline $3 \mathrm{mC}$ & $4.97 \pm 0.69(5)$ & $15.79 \pm 2.40(6)$ & $74.6 \pm 6.7(6)$ \\
$3 \mathrm{mD}$ & N.C. & N.C. & $0.0 \pm 0.0(6)^{\mathrm{f}}$ \\
$7 \mathrm{mC}$ & $6.39 \pm 1.05(5)$ & $15.76 \pm 3.41(5)$ & $75.0 \pm 4.5(5)$ \\
$7 \mathrm{mD}$ & N.C. & N.C. & $30.9 \pm 5.9(5)^{\mathrm{f}}$ \\
$7 \mathrm{mC} / 4 \mathrm{wS}$ & $3.01 \pm 0.32(6)$ & $30.38 \pm 3.96(6)$ & $74.6 \pm 6.6(6)$ \\
$7 \mathrm{mC} / 4 \mathrm{wF}$ & $4.20 \pm 0.26(6)^{\mathrm{c}}$ & $4.10 \pm 0.75(6)^{\mathrm{f}}$ & $165.1 \pm 14.7(6)^{\mathrm{f}}$ \\
$7 \mathrm{mD} / 2 \mathrm{wF}$ & $4.26 \pm 1.00(6)$ & $8.54 \pm 2.87(6)$ & $119.9 \pm 7.4(6)$ \\
$7 \mathrm{mD} / 4 \mathrm{WF}$ & $4.62 \pm 0.42(6)$ & $5.33 \pm 1.38(6)$ & $128.3 \pm 24.5(6)$ \\
\hline
\end{tabular}

Same presentation as in Table II. N.C.: not calculable.

Table V. Absolute values (mg/g) for C20:5 13 and C22:6 133 weight content of liver phospholipids.

\begin{tabular}{lrr}
\hline Rat & $\mathrm{C} 20: 5 \omega 3$ & \multicolumn{1}{c}{$\mathrm{C} 22: 6 \omega 3$} \\
\hline $7 \mathrm{mC}$ & $0.28 \pm 0.06(5)$ & $3.61 \pm 0.24(5)$ \\
$7 \mathrm{mC} / 4 \mathrm{wF}$ & $0.97 \pm 0.14(6)$ & $3.49 \pm 0.23(6)$ \\
$\quad$ - increment & $+0.69 \pm 0.17(9)$ & $-0.12 \pm 0.34(9)$ \\
$7 \mathrm{mD}$ & $0.00 \pm 0.00(6)$ & $0.66 \pm 0.04(6)$ \\
$7 \mathrm{mD} / 4 \mathrm{wF}$ & $0.81 \pm 0.12(6)$ & $3.56 \pm 0.30(6)$ \\
- increment & $+0.81 \pm 0.12(10)$ & $+2.90 \pm 0.30(10)$ \\
\hline
\end{tabular}

Values are means $\pm \mathrm{SE}$; nos. in parentheses indicate the no. of individual determinations (lower case) or degree of freedom (italics).

$(6.94 \pm 1.59 ; \mathrm{n}=12)$ than in the control animals $(15.77 \pm 1.92$; $\mathrm{n}=11)$. Inversely, the $\mathrm{C} 22: 5 \omega 3 / \mathrm{C} 22: 6 \omega 3$ ratio in liver phospholipids was higher $(\mathrm{p}<0.005)$ in the $\omega 3 \mathrm{D}$ rats given access to the $\omega 3$-enriched diet $(124.1 \pm 12.3 \%$; $n=12)$ than in the control animals $(74.8 \pm 4.0 \%$; $n=11)$. The latter value was itself higher $(p<0.001)$ than that recorded in the $\omega 3 \mathrm{D}$ rats also examined during the first 7 months of the present experiments (Table IV).

Table V provides the absolute values for the C20:5 03 and C22:6w3 content of liver phospholipids in the control animals and $\omega 3 \mathrm{D}$ rats examined shortly before and 4-5 weeks after exposure to the flaxseed oil-enriched diets. In both the control animals and $\omega 3 \mathrm{D}$ rats, the liver phospholipid content in $\mathrm{C} 20: 5 \omega 3$ was increased ( $\mathrm{p}<0.005$ or less) as a result of exposure to the $\omega 3$-enriched diet. Such an increase failed to differ significantly $(\mathrm{p}>0.5)$ in the control animals and $\omega 3 \mathrm{D}$ rats. The liver phospholipid content in C22:6w3 failed, however, to change significantly $(\mathrm{p}>0.7)$ in the control rats during exposure to the flaxseed oil-enriched diet. In the $\omega 3 \mathrm{D}$ rats, such a content increased by $2.90 \pm 0.30 \mathrm{mg} / \mathrm{g}(\mathrm{df}=10 ; \mathrm{p}<0.001)$, the latter value being significantly different $(\mathrm{p}<0.001)$ from both the change in the $\mathrm{C} 22: 6 \mathrm{\omega} 3$ content of liver phospholipids in the control animals also exposed for 4-5 weeks to the $\omega 3$-enriched diet and the increase in the C20:5 133 content of liver phospholipids in the same $\omega 3 \mathrm{D}$ rats.

Long-chain polyunsaturated $\omega 6$ fatty acids. The weight

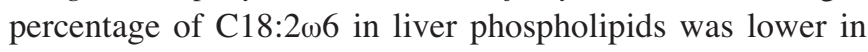
$\omega 3 \mathrm{D}$ rats than in control animals (Table VI). This coincided

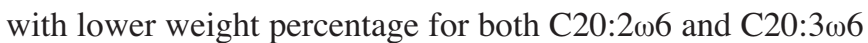
in the $\omega 3 \mathrm{D}$ rats than in the control animals. Relative to the mean corresponding values found at the same age in the latter animals, the values recorded in the $\omega 3 \mathrm{D}$ rats indeed averaged $82.8 \pm 6.3 \%(\mathrm{df}=21 ; \mathrm{p}<0.02)$ in the case of $\mathrm{C} 20: 2 \omega 6$ and $75.4 \pm 5.8 \%(\mathrm{df}=21 ; \mathrm{p}<0.001)$ in the case of $\mathrm{C} 20: 3 \omega 6$, these two percentages failing to differ significantly $(\mathrm{p}>0.3)$ from one another. The weight percentages of $\mathrm{C} 20: 4 \omega 6$ and $\mathrm{C} 22: 4 \omega 6$ in liver phospholipids were much higher, however, in $\omega 3 \mathrm{D}$ rats than in control animals. Even the weight percentage of $\mathrm{C} 18: 3 \omega 6$ was higher $(\mathrm{p}<0.05)$ in the $\omega 3 \mathrm{D}$ rats than in the control animals, averaging in the former rats $159.1 \pm 19.8 \%$ $(n=12)$ of the mean corresponding values found at the same age in the control animals $(100.0 \pm 15.7 \% ; n=11)$.

Exposure of the control rats to the soybean oil-enriched diet failed, as a rule, to affect the weight percentage of longchain polyunsaturated $\omega 6$ fatty acids in liver phospholipids.

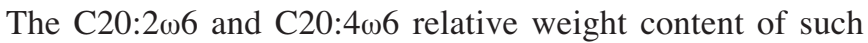
phospholipids was somewhat higher $(\mathrm{p}<0.01$ or less), however, in these rats than the mean corresponding value found in the control rats during the first 7 months of the present experiments. When compared to the control rats fed for 4-5 weeks the soybean oil-enriched diet, the control rats exposed for the same period to the flaxseed oil-enriched diet displayed a higher relative weight content of $\mathrm{C} 18: 2 \omega 6$ and lower relative

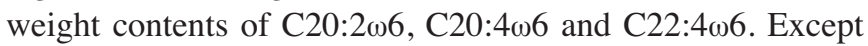
in the case of $\mathrm{C} 20: 2 \omega 6$, such differences represent a mirror image of those otherwise provoked by exposure of the rats to an $\omega 3$-deprived diet. The results recorded in the control rats after exposure to the flaxseed oil-enriched diet also differed from those recorded in the control rats before such an exposure

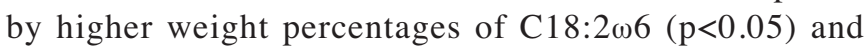
$\mathrm{C} 20: 3 \omega 6(\mathrm{p}<0.005)$ and lower weight percentages of $\mathrm{C} 20: 2 \omega 6$ $(\mathrm{p}<0.01), \mathrm{C} 20: 4 \omega 6(\mathrm{p}<0.001)$ and $\mathrm{C} 22: 4 \omega 6(\mathrm{p}<0.025)$.

In the $\omega 3 \mathrm{D}$ rats given access for $2-5$ weeks to the $\omega 3$ enriched diet, the weight percentage of $\mathrm{C} 18: 2 \omega 6(11.4 \pm 0.4 \%$; 
Table VI. Weight percentage of long-chain polyunsaturated $\omega 6$ fatty acids in liver phospholipids.

\begin{tabular}{lclllll}
\hline Rat & $\mathrm{C} 18: 2 \omega 6$ & $\mathrm{C} 18: 3 \omega 6$ & $\mathrm{C} 20: 2 \omega 6$ & $\mathrm{C} 20: 3 \omega 6$ & $\mathrm{C} 20: 4 \omega 6$ & $\mathrm{C} 22: 4 \omega 6$ \\
\hline $3 \mathrm{mC}$ & $12.8 \pm 0.6(6)$ & $0.1 \pm 0.0(6)$ & $0.4 \pm 0.0(6)$ & $0.6 \pm 0.0(6)$ & $27.0 \pm 0.7(6)$ & $0.1 \pm 0.0(6)$ \\
$3 \mathrm{mD}$ & $9.3 \pm 0.2(6)^{\mathrm{f}}$ & $0.2 \pm 0.0(6)$ & $0.3 \pm 0.0(6)$ & $0.4 \pm 0.0(6)^{\mathrm{f}}$ & $38.4 \pm 0.3(6)^{\mathrm{f}}$ & $1.0 \pm 0.1(6)^{\mathrm{f}}$ \\
$7 \mathrm{mC}$ & $13.8 \pm 0.9(5)$ & $0.2 \pm 0.0(5)$ & $0.3 \pm 0.0(5)$ & $0.6 \pm 0.0(5)$ & $27.1 \pm 0.8(5)$ & $0.2 \pm 0.0(5)$ \\
$7 \mathrm{mD}$ & $10.2 \pm 0.7(6)^{\mathrm{c}}$ & $0.3 \pm 0.0(6)^{\mathrm{c}}$ & $0.3 \pm 0.0(6)^{\mathrm{c}}$ & $0.5 \pm 0.0(6)^{\mathrm{a}}$ & $39.1 \pm 0.4(6)^{\mathrm{f}}$ & $1.0 \pm 0.0(6)^{\mathrm{f}}$ \\
$7 \mathrm{mC} / 4 \mathrm{wS}$ & $13.7 \pm 0.3(6)$ & $0.1 \pm 0.0(6)$ & $0.5 \pm 0.0(6)$ & $0.7 \pm 0.1(6)$ & $29.6 \pm 0.6(6)$ & $0.2 \pm 0.0(6)$ \\
$7 \mathrm{mC} / 4 \mathrm{wF}$ & $15.0 \pm 0.4(6)^{\mathrm{a}}$ & $0.1 \pm 0.0(6)$ & $0.3 \pm 0.0(6)^{\mathrm{f}}$ & $0.8 \pm 0.0(6)$ & $23.6 \pm 0.5(6)^{\mathrm{f}}$ & $0.1 \pm 0.0(6)^{\mathrm{f}}$ \\
$7 \mathrm{mD} / 2 \mathrm{wF}$ & $11.1 \pm 0.2(6)$ & $0.2 \pm 0.0(6)$ & $0.2 \pm 0.0(6)$ & $0.7 \pm 0.1(6)$ & $27.0 \pm 1.2(6)$ & $0.1 \pm 0.0(6)$ \\
$7 \mathrm{mD} / 4 \mathrm{wF}$ & $11.7 \pm 0.8(6)$ & $0.2 \pm 0.0(6)$ & $0.2 \pm 0.0(6)$ & $0.7 \pm 0.0(6)$ & $26.1 \pm 0.4(6)$ & $0.1 \pm 0.0(6)$ \\
\hline $\mathrm{Sm}$ & & & & & &
\end{tabular}

Same presentation as in Table II.

Table VII. Ratio between selected long-chain polyunsaturated $\omega 6$ fatty acids in liver phospholipids.

\begin{tabular}{lccccc}
\hline Rats & $\mathrm{C} 20: 2 \omega 6 / \mathrm{C} 18: 2 \omega 6\left(10^{-3}\right)$ & $\mathrm{C} 18: 3 \omega 6 / \mathrm{C} 18: 2 \omega 6\left(10^{-3}\right)$ & $\mathrm{C} 20: 3 \omega 6 / \mathrm{C} 18: 3 \omega 6$ & $\mathrm{C} 20: 4 \omega 6 / \mathrm{C} 20: 3 \omega 6$ & $\mathrm{C} 22: 4 \omega 6 / \mathrm{C} 20: 4 \omega 6\left(10^{-3}\right)$ \\
\hline $3 \mathrm{mC}$ & $29.2 \pm 2.0(6)$ & $9.7 \pm 1.0(5)$ & $5.1 \pm 0.6(5)$ & $44.3 \pm 3.3(5)$ & $6.5 \pm 0.2(5)$ \\
$3 \mathrm{mD}$ & $35.9 \pm 2.6(6)^{\mathrm{a}}$ & $21.3 \pm 3.9(5)^{\mathrm{c}}$ & $2.4 \pm 0.3(5) \mathrm{e}$ & $91.7 \pm 7.8(6)^{\mathrm{f}}$ & $25.8 \pm 1.7(6)^{\mathrm{f}}$ \\
$7 \mathrm{mC}$ & $24.2 \pm 1.3(5)$ & $11.4 \pm 1.7(5)$ & $4.3 \pm 0.5(5)$ & $44.4 \pm 3.9(5)$ & $7.2 \pm 0.4(5)$ \\
$7 \mathrm{mD}$ & $25.2 \pm 1.7(6)$ & $26.7 \pm 1.9(6)^{\mathrm{f}}$ & $1.9 \pm 0.1(6)^{\mathrm{f}}$ & $76.2 \pm 2.1(6)^{\mathrm{f}}$ & $25.6 \pm 1.3(6)^{\mathrm{f}}$ \\
$7 \mathrm{mC} / 4 \mathrm{wS}$ & $35.4 \pm 2.5(6)$ & $10.9 \pm 1.3(6)$ & $4.7 \pm 0.7(6)$ & $47.2 \pm 4.7(6)$ & $6.4 \pm 0.3(6)$ \\
$7 \mathrm{mC} / 4 \mathrm{wF}$ & $18.1 \pm 1.1(6)^{\mathrm{f}}$ & $9.2 \pm 0.3(6)$ & $6.0 \pm 0.3(6)$ & $30.9 \pm 1.3(6)^{\mathrm{d}}$ & $4.4 \pm 0.2(6)^{\mathrm{f}}$ \\
$7 \mathrm{mD} / 2 \mathrm{wF}$ & $16.9 \pm 1.1(6)$ & $13.8 \pm 1.2(6)$ & $4.8 \pm 0.6(6)$ & $41.4 \pm 6.0(6)$ & $5.2 \pm 0.3(6)$ \\
$7 \mathrm{mD} / 4 \mathrm{wF}$ & $14.2 \pm 1.2(6)$ & $13.2 \pm 0.6(6)$ & $4.7 \pm 0.2(6)$ & $37.3 \pm 2.5(6)$ & $5.0 \pm 0.4(6)$ \\
\hline
\end{tabular}

Same presentation as in Table II.

$\mathrm{n}=12)$ was higher $(\mathrm{p}<0.01)$ than that recorded in the $\omega 3 \mathrm{D}$ rats during the first 7 months of the present experiments $(9.7 \pm 0.4 \%$; $\mathrm{n}=12)$, but remained nevertheless lower $(\mathrm{p}<0.02)$ than that found over the same period of 7 months in the control animals $(13.3 \pm 0.5 \% ; \mathrm{n}=11)$. Likewise, the weight percentage of $\mathrm{C} 20: 2 \omega 6$ remained lower $(\mathrm{p}<0.001)$ in the $\omega 3 \mathrm{D}$ rats exposed to the $\omega 3$-enriched diet $(0.18 \pm 0.01 \% ; n=12)$ than in the control animals $(0.35 \pm 0.02 \% ; n=11)$. The weight percentages of $\mathrm{C} 18: 3 \omega 3, \mathrm{C} 20: 3 \omega 6, \mathrm{C} 20: 4 \omega 6$ and $\mathrm{C} 22: 4 \omega 6$ changed rapidly and markedly, however, in response to the exposure of the $\omega 3 \mathrm{D}$ rats to the $\omega 3$-enriched diet, reaching values comparable to those recorded in the control animals.

As judged from the ratio between selected long-chain polyunsaturated $\omega 6$ fatty acids in liver phospholipids, the activity of $\Delta 6$-desaturase $(\mathrm{C} 18: 3 \omega 6 / \mathrm{C} 18: 2 \omega 6)$ and $\Delta 5$ -

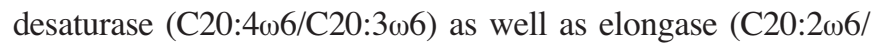
C18:2 $\omega 6$ and $\mathrm{C} 22: 4 \omega 6 / \mathrm{C} 20: 4 \omega 6)$, appeared, as a rule, significantly higher in $\omega 3 \mathrm{D}$ rats than in control animals (Table VII). Only the C20:3 $\omega 6 / \mathrm{C} 18: 3 \omega 6$ ratio was significantly lower in $\omega 3 \mathrm{D}$ rats than in control animals. Except for a significant increase $(p<0.01)$ in the phospholipid C20:2 $\omega 6 /$ $\mathrm{C} 18: 2 \omega 6$ ratio, the exposure of the control rats to the soybean oil-enriched diet failed to affect significantly the ratio between selected long-chain polyunsaturated $\omega 6$ fatty acids. Compared to the values recorded in these control rats exposed to the soybean oil-enriched diet, those recorded in the control rats exposed to the flaxseed oil-enriched diet demonstrated

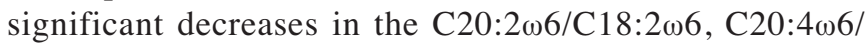
$\mathrm{C} 20: 3 \omega 6$ and $\mathrm{C} 22: 4 \omega 6 / \mathrm{C} 20: 4 \omega 6$ ratios, all these differences representing a mirror image of those otherwise caused by exposure of the rats to the $\omega 3$-deprived diet.

When the $\omega 3 \mathrm{D}$ rats were given access to the $\omega 3$-enriched diet, the phospholipid $\mathrm{C} 20: 2 \omega 6 / \mathrm{C} 18: 2 \omega 6$ ratio became lower $(\mathrm{p}<0.001)$ than that recorded in the control animals. The

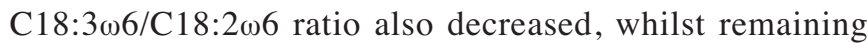
slightly higher $(\mathrm{p}<0.02)$ than that recorded in the control animals. The $\mathrm{C} 20: 3 \omega 6 / \mathrm{C} 18: 3 \omega 6$ and $\mathrm{C} 20: 4 \omega 6 / \mathrm{C} 20: 3 \omega 6$ ratios resumed values comparable ( $\mathrm{p}>0.2$ or more) to those found in control rats. The $\mathrm{C} 22: 4 \omega 6 / \mathrm{C} 20: 4 \omega 6$ ratio event became significantly lower $(\mathrm{p}<0.001)$ than that measured in the control animals.

A last finding duly merits to be underlined. The results so far presented do not refer to the C22:5 $\omega 6$ content of liver phospholipids because it had not been measured in our usual procedure. Nevertheless, it should not be ignored that such a content was close to the limit of detection in control rats, whilst being far-from-negligible in $\omega 3 \mathrm{D}$ rats. For instance, after 3 and 7 months of dietary $\omega 3$ deprivation, it averaged, respectively, $1.82 \pm 2.8$ and $1.34 \pm 0.14 \mathrm{mg} / \mathrm{g}$ wet weight $(\mathrm{n}=6$ in both cases). These two mean values, which did not differ 
Table VIII. Weight percentage of saturated and monodesaturated fatty acids in liver phospholipids.

\begin{tabular}{|c|c|c|c|c|c|}
\hline Rats & $\mathrm{C} 14: 0$ & C16:0 & 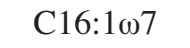 & C18:0 & 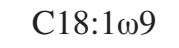 \\
\hline $3 \mathrm{mC}$ & $0.1 \pm 0.0$ & $13.5 \pm 0.4(6)$ & $0.2 \pm 0.0(6)$ & $21.0 \pm 0.4(6)$ & $1.9 \pm 0.2(6)$ \\
\hline $3 \mathrm{mD}$ & $0.3 \pm 0.1(6)$ & $15.4 \pm 0.2(6)^{\mathrm{e}}$ & $0.5 \pm 0.1(6)^{\mathrm{e}}$ & $25.9 \pm 0.4(6)^{\mathrm{f}}$ & $2.4 \pm 0.1(6)^{\mathrm{a}}$ \\
\hline $7 \mathrm{mC}$ & $0.2 \pm 0.0(5)$ & $13.7 \pm 0.2(5)$ & $0.3 \pm 0.0$ & $21.0 \pm 0.4(5)$ & $2.0 \pm 0.2(5)$ \\
\hline $7 \mathrm{mD}$ & $0.3 \pm 0.0(6)^{\mathrm{f}}$ & $14.4 \pm 0.5(6)$ & $0.6 \pm 0.0(6)^{\mathrm{e}}$ & $25.5 \pm 0.6(6)^{f}$ & $2.8 \pm 0.1(6)^{\mathrm{e}}$ \\
\hline $7 \mathrm{mC} / 4 \mathrm{wS}$ & $0.2 \pm 0.0(6)$ & $13.4 \pm 0.4(6)$ & $0.2 \pm 0.0(6)$ & $20.5 \pm 0.4(6)$ & $2.1 \pm 0.1(6)$ \\
\hline $7 \mathrm{mC} / 4 \mathrm{wF}$ & $0.2 \pm 0.0(6)$ & $12.6 \pm 0.3(6)$ & $0.2 \pm 0.0(6)$ & $22.3 \pm 0.3(6)^{\mathrm{d}}$ & $2.3 \pm 0.2(6)$ \\
\hline $7 \mathrm{mD} / 2 \mathrm{wF}$ & $0.1 \pm 0.0(6)$ & $12.0 \pm 0.4(6)$ & $0.4 \pm 0.1(6)$ & $23.6 \pm 0.4(6)$ & $2.3 \pm 0.0(6)$ \\
\hline $7 \mathrm{mD} / 4 \mathrm{wF}$ & $0.2 \pm 0.0$ & $12.5 \pm 0.4(6)$ & $0.4 \pm 0.1$ & $23.2 \pm 0.4(6)$ & $2.1 \pm 0.1$ \\
\hline Rats & C20:0 & C20:1 $1 \omega 9$ & $\mathrm{C} 22: 0$ & $\mathrm{C} 22: 1 \omega 9$ & $\mathrm{C} 24: 0$ \\
\hline $3 \mathrm{mC}$ & $0.1 \pm 0.0(6)$ & $0.1 \pm 0.0(6)$ & $0.3 \pm 0.0(6)$ & $0.2 \pm 0.1(6)$ & $0.8 \pm 0.0$ \\
\hline $3 \mathrm{mD}$ & $0.1 \pm 0.0(6)$ & $0.0 \pm 0.0$ & $0.4 \pm 0.0$ & $0.2 \pm 0.1(6)$ & $1.1 \pm 0.0(6)^{\mathrm{f}}$ \\
\hline $7 \mathrm{mC}$ & $0.1 \pm 0.0(5)$ & $0.1 \pm 0.0(5)$ & $0.3 \pm 0.0$ & $0.2 \pm 0.1(5)$ & $0.9 \pm 0.1(5)$ \\
\hline $7 \mathrm{mD}$ & $0.1 \pm 0.0$ & $0.1 \pm 0.0$ & $0.4 \pm 0.0(6)^{\mathrm{f}}$ & $0.1 \pm 0.0(6)$ & $1.1 \pm 0.0(6)$ \\
\hline $7 \mathrm{mC} / 4 \mathrm{wS}$ & $0.1 \pm 0.0(6)$ & $0.1 \pm 0.0(6)$ & $0.3 \pm 0.0(6)$ & $0.4 \pm 0.0$ & $0.9 \pm 0.0(6)$ \\
\hline $7 \mathrm{mC} / 4 \mathrm{wF}$ & $0.1 \pm 0.0$ & $0.1 \pm 0.0(6)$ & $0.3 \pm 0.0(6)^{\mathrm{e}}$ & $0.2 \pm 0.0(6)^{\mathrm{d}}$ & $0.9 \pm 0.0(6)$ \\
\hline $7 \mathrm{mD} / 2 \mathrm{wF}$ & $0.1 \pm 0.0(6)$ & $0.0 \pm 0.0(6)$ & $0.3 \pm 0.0$ & $0.2 \pm 0.0$ & $0.9 \pm 0.0(6)$ \\
\hline $7 \mathrm{mD} / 4 \mathrm{wF}$ & $0.1 \pm 0.0(6)$ & $0.0 \pm 0.0(6)$ & $0.4 \pm 0.0$ & $0.3 \pm 0.1(6)$ & $1.0 \pm 0.0(6)$ \\
\hline
\end{tabular}

Same presentation as in Table II.

significantly $(\mathrm{p}>0.1)$ from one another, yielded a relative weight content of $\mathrm{C} 22: 5 \omega 6$ in the liver phospholipids of $\omega 3 \mathrm{D}$ rats averaging $8.0 \pm 0.5 \%(\mathrm{n}=12)$. The $\mathrm{C} 22: 5 \omega 6 / \mathrm{C} 22: 4 \omega 6$ ratio averaged, in the same rats, $8.98 \pm 0.76(n=12)$.

Saturated and monodesaturated fatty acids. No C12:0 was detected in the liver phospholipids of any animal. With the

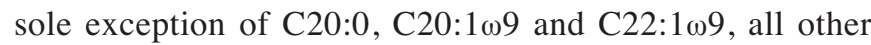
saturated and monodesaturated fatty acids (C14:0, C16:0,

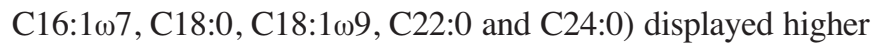
mean values for their relative weight content in $\omega 3 \mathrm{D}$ rats than in control animals (Table VIII). Such an increase was most obvious and achieved statistical significance at both the 3rd and 7 th month of the present experiments in the case of

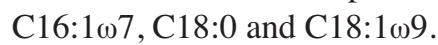

When the control rats were exposed for 4 weeks to the soybean oil-enriched diet, the weight percentage of C14:0 $(\mathrm{p}<0.06), \mathrm{C} 20: 0(\mathrm{p}<0.005)$ and $\mathrm{C} 22: 0(\mathrm{p}<0.001)$ in liver phospholipids became higher than that recorded in the control animals at the end of the 7 first months in the present experiments, whilst the weight percentage of $\mathrm{C} 16: 1 \omega 7$ became lower $(p<0.005)$ in the former rats than in the latter animals. As a rule, there was little to distinguish between the control animals given access to either the soybean or flaxseed oilenriched diet, except for a higher C18:0 $(\mathrm{p}<0.01)$ and lower $\mathrm{C} 22: 0(\mathrm{p}<0.005)$ relative content in the liver phospholipids of the latter animals, as compared to former ones.

In the $12 \omega 3 \mathrm{D}$ rats given access to the $\omega 3$-enriched diet, the weight percentage of $\mathrm{C} 14: 0(\mathrm{p}<0.025), \mathrm{C} 16: 0(\mathrm{p}<0.001)$,

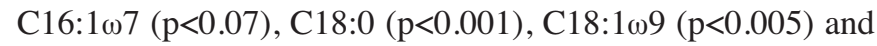

C24:0 $(\mathrm{p}<0.005)$ were all lower than in the $12 \omega 3 \mathrm{D}$ rats examined during the first 7 months of the present experiments.

The $\mathrm{C} 16: 1 \omega 7 / \mathrm{C} 16: 0$ ratio was higher in $\omega 3 \mathrm{D}$ rats than in control animals, whilst there was little to distinguish between $\omega 3 \mathrm{D}$ and control rats in the case of the $\mathrm{C} 18: 1 \omega 9 / \mathrm{C} 18: 0$ ratio (Table IX). The $(\mathrm{C} 18: 0+\mathrm{C} 18: 1 \omega 9) /(\mathrm{C} 16: 0+\mathrm{C} 16: 1 \omega 7)$ ratio of liver phospholipids was higher $(\mathrm{p}<0.005)$ in the $\omega 3 \mathrm{D}$ rats $(1.84 \pm 0.04 ; n=12)$ than in the control animals $(1.65 \pm 0.04$; $\mathrm{n}=11$ ). When the control rats were given access to either the soybean or flaxseed oil-enriched diet, the C16:107/C16:0 ratio became lower $(\mathrm{p}<0.05)$ than that recorded in the control rats during the first 7 months of the present experiments (20.0 $\pm 1.6 ; \mathrm{n}=11)$, whilst the $\mathrm{C} 18: 1 \omega 9 / \mathrm{C} 18: 0$ ratio remained unchanged. The $(\mathrm{C} 18: 0+\mathrm{C} 18: 1 \omega 9 /(\mathrm{C} 16: 0+\mathrm{C} 16: 1 \omega 7)$ ratio also failed to be affected when the control animals were exposed to the soybean oil-enriched diet. In the control animals exposed to the flaxseed oil-enriched diet, however, such a ratio became unexpectedly higher $(\mathrm{p}<0.005)$ than that recorded in the control animals during the 7 first months of the experiments.

The activity of $\Delta 9$-desaturase as judged from the

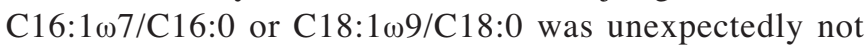
significantly different in $\omega 3 \mathrm{D}$ rats exposed to either the $\omega 3$-depleted or $\omega 3$-enriched diet. In the latter animals, the activity of elongase, as judged from the (C18:0/C18:1w9)/ $(\mathrm{C} 16: 0 / \mathrm{C} 16: 1 \omega 7)$ ratio was even further increased in the $\omega 3 \mathrm{D}$ rats given access to the $\omega 3$-enriched diet, the values recorded in these rats $(2.03 \pm 0.06 ; n=12)$ being higher $(\mathrm{p}<0.025)$ than that recorded in the $\omega 3 \mathrm{D}$ rats when exposed to the $\omega 3$-depleted $\operatorname{diet}(1.84 \pm 0.04 ; \mathrm{n}=12)$. 
Table IX. Ratio between selected saturated and monodesaturated fatty acids in liver phospholipids.

\begin{tabular}{lccc}
\hline Rats & $\mathrm{C} 16: 1 \omega 7 / \mathrm{C} 16: 0\left(10^{-3}\right)$ & $\mathrm{C} 18: 1 \omega 9 / \mathrm{C} 18: 0\left(10^{-3}\right)$ & $(\mathrm{C} 18: 0+\mathrm{C} 18: 1 \omega 9) /(\mathrm{C} 16: 0+\mathrm{C} 16: 1 \omega 7)$ \\
\hline $3 \mathrm{mC}$ & $17.0 \pm 1.1(6)$ & $89.6 \pm 9.6(6)$ & $1.67 \pm 0.07(6)$ \\
$3 \mathrm{mD}$ & $31.6 \pm 3.7(6)^{\mathrm{e}}$ & $91.4 \pm 3.8(6)$ & $1.78 \pm 0.04(6)$ \\
$7 \mathrm{mC}$ & $23.5 \pm 2.5(5)$ & $95.6 \pm 8.9(5)$ & $1.63 \pm 0.03(5)$ \\
$7 \mathrm{mD}$ & $36.2 \pm 2.1(6)^{\mathrm{e}}$ & $108.0 \pm 6.1(6)$ & $1.90 \pm 0.06(6)$ \\
$7 \mathrm{mC} / 4 \mathrm{wS}$ & $12.3 \pm 1.3(6)$ & $101.3 \pm 7.0(6)$ & $1.68 \pm 0.09(6)$ \\
$7 \mathrm{mC} / 4 \mathrm{wF}$ & $14.5 \pm 1.1(6)$ & $104.3 \pm 8.1(6)$ & $2.09 \pm 0.08(6)$ \\
$7 \mathrm{mD} / 2 \mathrm{wF}$ & $31.0 \pm 6.1(6)$ & $96.5 \pm 1.8(6)$ & $1.96 \pm 0.10(6)$ \\
$7 \mathrm{mD} / 4 \mathrm{wF}$ & $34.2 \pm 4.4(6)$ & $89.5 \pm 6.7(6)$ & \\
\hline
\end{tabular}

Same presentation as in Table II.

Monodesaturated $\omega 9$ fatty acids. At variance with the findings made for most saturated and monodesaturated fatty acids and despite the higher weight percentage of $\mathrm{C} 18: 1 \omega 9$ in the liver phospholipids of $\omega 3 \mathrm{D}$ rats, that of further precursors of nervonic acid (C20:1 $\omega 9$ and $C 22: 1 \omega 9)$ only represented in the $\omega 3 \mathrm{D}$ rats examined 3 and 7 months after the onset of the present experiments respectively $53.4 \pm 15.5 \% \quad(n=12)$ and $58.3 \pm 6.0 \%(n=12)$ of the mean corresponding values recorded at the same age in control animals. Over this period, the weight percentage of $\mathrm{C} 20: 1 \omega 9$ and $\mathrm{C} 22: 1 \omega 9$ in liver phospholipids of $\omega 3 \mathrm{D}$ rats thus averaged $55.8 \pm 8.2 \% \quad(n=24$; $\mathrm{p}<0.02$ ) of the mean corresponding values found for the same fatty acid(s) at the same age(s) in control animals $(100.0 \pm 14.7 \% ; n=22)$.

When the control animals were given access for 4-5 weeks to the soybean oil-enriched diet, the weight percentage of $\mathrm{C} 20: 1 \omega 9$ and $\mathrm{C} 22: 1 \omega 9$ was increased $(\mathrm{p}<0.05)$ to $159.3 \pm 12.0 \%(n=12)$ of the mean corresponding values recorded in the control animals exposed for 7 months to the control diet $(100.0 \pm 26.7 \% ; \mathrm{n}=10)$ and, as such, represented $168.6 \pm 13.6 \%(n=12 ; \mathrm{p}<0.002)$ of the mean corresponding values found in control animals exposed for 4-5 weeks to the flaxseed oil-enriched diet $(100.0 \pm 12.0 \% ; n=12)$. In other words, the weight percentage of $\mathrm{C} 20: 1 \omega 9$ and $\mathrm{C} 22: 1 \omega 9$ in liver phospholipids was virtually identical ( $p>0.8$ or more) in control animals just before and 4-5 weeks after exposure to the flaxseed oil-enriched diet.

In the $\omega 3 \mathrm{D}$ rats, the alteration in the relative content of nervonic acid precursors in liver phospholipids was apparently opposed, however, when these rats were given access to the $\omega 3$-enriched diet. The $\mathrm{C} 22: 1 \omega 9 / \mathrm{C} 18: 1 \omega 9$ ratio indeed increased $(\mathrm{p}<0.02)$ from a mean value of $5.7 \pm 1.1 \%(n=12)$ in the $\omega 3 \mathrm{D}$ rats examined during the first 7 months of the present experiments to $11.0 \pm 1.5 \%(n=12)$ in the $\omega 3 \mathrm{D}$ rats given access to the flaxseed oil-enriched diet, the latter value being virtually identical $(\mathrm{p}>0.8)$ to that recorded in the control animals $(11.5 \pm 2.9 \% ; n=11)$ also examined during the first 7 months of the present experiments. The latter values also failed to differ significantly $(\mathrm{p}>0.6)$ from that recorded in the control rats exposed for 4-5 weeks to the flaxseed oil-enriched diet $(9.4 \pm 1.2 \% ; n=6)$, which itself only represented half $(\mathrm{p}<0.005)$ of the $\mathrm{C} 22: 1 \omega 9 / \mathrm{C} 18: 1 \omega 9$ ratio found in the liver phospholipids of control animals exposed for 4-5 weeks to the soybean oilenriched diet $(19.9 \pm 2.3 \% ; n=6)$.

Liver triglycerides. Total fatty acid content. Whether after 3 or 7 months of exposure to the $\omega 3$-depleted diet, the total fatty acid content of liver triglycerides was significantly higher than that recorded at the same age in the control animals (Table II). Likewise, already 3 months after exposure to the $\omega 3$-depleted diet, the glycerol content of triglycerides was already significantly higher $(\mathrm{p}<0.05)$ in $\omega 3 \mathrm{D}$ rats $(6.42 \pm 0.50 \mu \mathrm{mol} / \mathrm{g} ; \mathrm{n}=6)$ than in control animals $(4.16 \pm 0.25$ $\mu \mathrm{mol} / \mathrm{g} ; \mathrm{n}=6)$. At that time, the relative magnitude of the increase in the triglyceride liver content was not significantly different $(\mathrm{p}>0.1)$ whether judged from their fatty acid or glycerol content, with an overall mean value of $75.1 \pm 13.4 \%$ $(\mathrm{df}=20 ; \mathrm{p}<0.001)$.

When the control rats were exposed for 4-5 weeks to the soybean oil-enriched diet, the total fatty acid content of liver triglycerides, as well as the ratio between such a content and the total fatty acid content of liver phospholipids, became higher $(\mathrm{p}<0.05$ or less) than that found in the control rats before such an exposure. In respect to these two variables, there was no significant difference between the control animals eventually exposed to either the soybean oil-enriched diet or flaxseed oil-enriched diet.

Likewise, the total fatty acid content of liver triglycerides was higher $(\mathrm{p}<0.05)$ in the $12 \omega 3 \mathrm{D}$ rats exposed for $2-5$ weeks before sacrifice to the $\omega 3$-enriched diet $(6.94 \pm 0.92 \mathrm{mg} / \mathrm{g})$ than in the $12 \omega 3 \mathrm{D}$ rats exposed for 3-7 months to the $\omega 3$ depleted diet $(4.89 \pm 0.31 \mathrm{mg} / \mathrm{g})$.

In the $\omega 3 \mathrm{D}$ rats, the triglyceride/phospholipid ratio for the total fatty acid content of these liver lipids failed, however, to differ significantly $(\mathrm{p}>0.15)$ after exposure to the $\omega 3$-enriched diet $(0.297 \pm 0.032 ; n=12)$ and before such an exposure $(0.248 \pm 0.018 ; n=11)$, both latter mean values being much higher $(\mathrm{p}<0.001)$ than that recorded in the control animals during the first 7 months of the present experiments $(0.112 \pm 0.011 ; n=10)$. In the $\omega 3 \mathrm{D}$ rats exposed for $4-5$ weeks to the flaxseed oil-enriched diet, the mean values for the total fatty acid content of liver triglycerides and for the triglyceride/ phospholipid ratio for total fatty acid content were higher than those recorded in the control animals also exposed for 
Table X. Weight percentage of long-chain polyunsaturated $\omega 3$ fatty acids in liver triglycerides.

\begin{tabular}{lllll}
\hline Rats & $\mathrm{C} 18: 3 \omega 3$ & $\mathrm{C} 20: 5 \omega 3$ & $\mathrm{C} 22: 5 \omega 3$ & $\mathrm{C} 22: 6 \omega 3$ \\
\hline $3 \mathrm{mC}$ & $2.7 \pm 0.2(6)$ & $1.2 \pm 0.3(6)$ & $1.6 \pm 0.1(6)$ & $4.7 \pm 0.3(6)$ \\
$3 \mathrm{mD}$ & $0.0 \pm 0.0(6)^{\mathrm{f}}$ & $0.0 \pm 0.0(6)^{\mathrm{e}}$ & $0.0 \pm 0.0(6)^{\mathrm{f}}$ & $0.1 \pm 0.1(6)^{\mathrm{f}}$ \\
$7 \mathrm{mC}$ & $2.3 \pm 0.2(5)$ & $1.5 \pm 0.4(5)$ & $1.5 \pm 0.2(5)$ & $4.2 \pm 0.7(5)$ \\
$7 \mathrm{mD}$ & $0.0 \pm 0.0(6)^{\mathrm{f}}$ & $0.0 \pm 0.0(6)^{\mathrm{e}}$ & $0.0 \pm 0.0(6)^{\mathrm{f}}$ & $0.0 \pm 0.0(6)^{\mathrm{f}}$ \\
$7 \mathrm{mC} / 4 \mathrm{wS}$ & $2.9 \pm 0.1(6)$ & $0.9 \pm 0.2(6)$ & $1.6 \pm 0.2(6)$ & $4.5 \pm 0.6(6)$ \\
$7 \mathrm{mC} / 4 \mathrm{wF}$ & $13.6 \pm 1.0(6)^{\mathrm{f}}$ & $3.5 \pm 0.3(6)^{\mathrm{f}}$ & $3.2 \pm 0.4(6)^{\mathrm{d}}$ & $3.7 \pm 0.4(6)$ \\
$7 \mathrm{mD} / 2 \mathrm{wF}$ & $10.6 \pm 1.3(6)$ & $1.6 \pm 0.2(6)$ & $1.3 \pm 0.1(6)$ & $1.5 \pm 0.1(6)$ \\
$7 \mathrm{mD} / 4 \mathrm{wF}$ & $12.6 \pm 0.7(6)$ & $1.6 \pm 0.0(6)$ & $1.3 \pm 0.1(6)$ & $1.5 \pm 0.2(6)$ \\
\hline
\end{tabular}

Same presentation as in Table II.

Table XI. Weight percentage of long-chain polyunsaturated $\omega 6$ fatty acids in liver triglycerides.

\begin{tabular}{lllllll}
\hline Rats & $\mathrm{C} 18: 2 \omega 6$ & $\mathrm{C} 18: 3 \omega 6$ & $\mathrm{C} 20: 2 \omega 6$ & $\mathrm{C} 20: 3 \omega 6$ & $\mathrm{C} 20: 4 \omega 6$ & $\mathrm{C} 22: 4 \omega 6$ \\
\hline $3 \mathrm{mC}$ & $41.1 \pm 1.0(6)$ & $0.1 \pm 0.1(6)$ & $0.0 \pm 0.0(6)$ & $0.0 \pm 0.0(6)$ & $4.9 \pm 0.3(6)$ & $0.4 \pm 0.2(6)$ \\
$3 \mathrm{mD}$ & $31.2 \pm 1.3(6)^{\mathrm{f}}$ & $0.7 \pm 0.1(6)^{\mathrm{d}}$ & $0.1 \pm 0.1(6)$ & $0.0 \pm 0.0(6)$ & $3.3 \pm 0.2(6)^{\mathrm{e}}$ & $0.6 \pm 0.0(6)$ \\
$7 \mathrm{mC}$ & $37.2 \pm 1.8(5)$ & $0.4 \pm 0.1(5)$ & $0.2 \pm 0.1(5)$ & $0.5 \pm 0.2(5)$ & $4.2 \pm 0.5(5)$ & $0.8 \pm 0.1(5)$ \\
$7 \mathrm{mD}$ & $28.1 \pm 2.5(6)^{\mathrm{c}}$ & $0.8 \pm 0.1(6)^{\mathrm{b}}$ & $0.2 \pm 0.1(6)$ & $0.0 \pm 0.0(6)^{\mathrm{a}}$ & $4.3 \pm 0.5(6)$ & $0.7 \pm 0.1(6)$ \\
$7 \mathrm{mC} / 4 \mathrm{wS}$ & $44.8 \pm 0.5(6)$ & $0.8 \pm 0.1(6)$ & $0.4 \pm 0.1(6)$ & $0.5 \pm 0.1(6)$ & $5.0 \pm 0.4(6)$ & $0.7 \pm 0.1(6)$ \\
$7 \mathrm{mC} / 4 \mathrm{wF}$ & $34.5 \pm 0.9(6)^{\mathrm{f}}$ & $0.3 \pm 0.1(6)^{\mathrm{d}}$ & $0.1 \pm 0.1(6)^{\mathrm{a}}$ & $0.3 \pm 0.1(6)$ & $2.8 \pm 0.1(6)^{\mathrm{f}}$ & $0.1 \pm 0.1(6)^{\mathrm{e}}$ \\
$7 \mathrm{mD} / 2 \mathrm{wF}$ & $30.1 \pm 2.6(6)$ & $0.5 \pm 0.1(6)$ & $0.1 \pm 0.0(6)$ & $0.1 \pm 0.1(6)$ & $2.8 \pm 0.3(6)$ & $0.1 \pm 0.1(6)$ \\
$7 \mathrm{mD} / 4 \mathrm{wF}$ & $29.6 \pm 0.8(6)$ & $0.5 \pm 0.0(6)$ & $0.0 \pm 0.0(6)$ & $0.0 \pm 0.0(6)$ & $2.1 \pm 0.2(6)$ & $0.1 \pm 0.1(6)$ \\
\hline
\end{tabular}

Same presentation as in Table II.

4-5 weeks to the flaxseed oil-enriched diet, the former mean values averaging $159.2 \pm 21.2 \%(n=12 ; p<0.02)$ of the corresponding mean values recorded in the control animals $(100.0 \pm 9.6 \% ; \mathrm{n}=12)$.

Long-chain polyunsaturated $\omega 3$ fatty acids. Whilst sizeable amounts of all long-chain polyunsaturated $\omega 3$ fatty acids

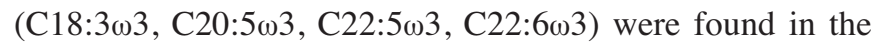
triglycerides of control animals, such was only once the case (C22:6w3 relative weight content: $0.3 \%$ ) out of a total of 48 measurements made in $\omega 3 \mathrm{D}$ rats (Table $\mathrm{X}$ ).

The relative weight content of long-chain polyunsaturated $\omega 3$ fatty acids in liver triglycerides were comparable in the control rats before and after exposure to the soybean oilenriched diet. Except in the case of $\mathrm{C} 22: 6 \omega 3$, higher values were recorded in the control rats exposed to the flaxseed oilenriched diet.

When the $\omega 3 \mathrm{D}$ rats were given access to the $\omega 3$-enriched diet, sizeable amounts of all four long-chain polyunsaturated $\omega 3$ fatty acids were invariably found in liver triglycerides. The weight percentage of $\mathrm{C} 18: 3 \omega 3$ was much higher $(\mathrm{p}<0.001)$ in these rats $(11.6 \pm 0.8 \% ; n=12)$ than in the control animals examined during the first 7 months of the present experiments $(2.5 \pm 0.1 \% ; n=4)$. The weight percentages of $\mathrm{C} 20: 5 \omega 3$ and
$\mathrm{C} 22: 5 \omega 3$, however, were not vastly different in these two groups of rats, whilst that of $\mathrm{C} 22: 6 \omega 3$ remained lower $(p<0.001)$ in the $\omega 3 \mathrm{D}$ rats exposed for $2-5$ weeks to the $\omega 3$ enriched diet $(1.5 \pm 0.1 \% ; \mathrm{n}=12)$ than in the control animals examined 3-7 months after the onset of the present experiments $(4.5 \pm 0.3 \% ; \mathrm{n}=11)$.

The C20:5 $\omega 3 / \mathrm{C} 18: 3 \omega 3, \mathrm{C} 22: 6 \omega 3 / \mathrm{C} 20: 5 \omega 3$ and $\mathrm{C} 22: 5 \omega 3 /$ $\mathrm{C} 22: 6 \omega 3$ ratios failed to differ significantly in the control rats examined during the first 7 months of the present experiments and the control animals eventually exposed to the soybean oil-enriched diet, with respective mean values of $0.52 \pm 0.07$ $(\mathrm{n}=11)$ and $0.32 \pm 0.08(\mathrm{n}=6)$ for the $\mathrm{C} 20: 5 \omega 3 / \mathrm{C} 18: 3 \omega 3$ ratio, $3.52 \pm 0.46(n=10)$ and $4.20 \pm 0.25(n=5)$ for the $C 22: 6 \omega 3 /$ $\mathrm{C} 20: 5 \omega 3$ ratio, and $0.36 \pm 0.01(\mathrm{n}=11)$ and $0.36 \pm 0.02(\mathrm{n}=6)$ for the $\mathrm{C} 22: 5 \omega 3 / \mathrm{C} 22: 6 \omega 3$. The $\mathrm{C} 20: 5 \omega 3 / \mathrm{C} 18: 3 \omega 3$ ratio also failed to differ significantly $(\mathrm{p}>0.4)$ in the control animals fed either the soybean or flaxseed oil-enriched diet. In the latter animals, however, the $\mathrm{C} 22: 6 \omega 3 / \mathrm{C} 20: 5 \omega 3$ ratio was much lower $(1.09 \pm 0.12 ; \mathrm{n}=6 ; \mathrm{p}<0.001)$ and the $\mathrm{C} 22: 5 \omega 3 / \mathrm{C} 22: 6 \omega 3$ twice higher $(0.85 \pm 0.06 ; \mathrm{n}=6 ; \mathrm{p}<0.001)$ than in the former animals.

The $\mathrm{C} 20: 5 \omega 3 / \mathrm{C} 18: 3 \omega 3$ ratio in liver triglycerides was much lower $(\mathrm{p}<0.001)$ in the $\omega 3 \mathrm{D}$ rats exposed for 2 to $4-5$ weeks to the $\omega 3$-enriched diet $(0.14 \pm 0.01 ; n=12)$ than in the control 
Table XII. Ratio between selected long-chain polyunsaturated $\omega 6$ fatty acids in liver triglycerides.

\begin{tabular}{lcccc}
\hline Rats & $\mathrm{C} 20: 2 \omega 6 / \mathrm{C} 18: 2 \omega 6\left(10^{-3}\right)$ & $\mathrm{C} 18: 3 \omega 6: \mathrm{C} 18: 2 \omega 6\left(10^{-3}\right)$ & $\mathrm{C} 20: 4 \omega 6 / \mathrm{C} 18: 2 \omega 6$ & $\mathrm{C} 22: 4 \omega 6 / \mathrm{C} 20: 4 \omega 6$ \\
\hline $3 \mathrm{mC}$ & N.A. & $20.7(1)$ & $0.117 \pm 0.006(6)$ & $0.170 \pm 0.031(3)$ \\
$3 \mathrm{mD}$ & $9.55 \pm 0.54(2)$ & $21.0 \pm 2.8(6)$ & $0.106 \pm 0.004(6)$ & $0.170 \pm 0.009(6)$ \\
$7 \mathrm{mC}$ & $12.56 \pm 0.45(2)$ & $13.8 \pm 2.0(4)$ & $0.113 \pm 0.011(5)$ & $0.202 \pm 0.052(5)$ \\
$7 \mathrm{mD}$ & $9.30 \pm 0.79(4)$ & $27.2 \pm 1.3(6)^{\mathrm{f}}$ & $0.153 \pm 0.008(6)^{\mathrm{c}}$ & $0.166 \pm 0.013(6)$ \\
$7 \mathrm{mC} / 4 \mathrm{wS}$ & $9.63 \pm 1.27(5)$ & $16.6 \pm 1.6(6)$ & $0.112 \pm 0.010(6)$ & $0.163 \pm 0.012(5)$ \\
$7 \mathrm{mC} / 4 \mathrm{wF}$ & $7.35 \pm 1.10(2)$ & $13.5 \pm 0.4(6)$ & $0.082 \pm 0.002(6)^{\mathrm{c}}$ & $0.116(1)^{\mathrm{c}}$ \\
$7 \mathrm{mD} / 2 \mathrm{wF}$ & $6.03 \pm 0.05(2)$ & $15.8 \pm 1.3(6)$ & $0.095 \pm 0.008(6)$ & $0.079 \pm 0.005(2)$ \\
$7 \mathrm{mD} / 4 \mathrm{wF}$ & $8.18(1)$ & $16.4 \pm 0.6(6)$ & $0.071 \pm 0.007(6)$ & $0.125(1)$ \\
\hline
\end{tabular}

Same presentation as in Table II. N.A., not applicable.

rats examined 139 and 264 days after birth $(0.52 \pm 0.07 ; \mathrm{n}=11)$. The $\mathrm{C} 22: 6 \omega 3 / \mathrm{C} 20: 5 \omega 3$ ratio was also lower $(\mathrm{p}<0.001)$ in the $\omega 3 \mathrm{D}$ rats exposed to the $\omega 3$-enriched diet for 2 to $4-5$ weeks before sacrifice $(0.99 \pm 0.08 ; \mathrm{n}=12)$ than in the control animals examined during the first 7 months of the present experiments (3.52 $\pm 0.46 ; n=10)$. Inversely, however, the $\mathrm{C} 22: 5 \omega 3 / \mathrm{C} 22: 6 \omega 3$ ratio was much higher $(\mathrm{p}<0.001)$ in the $\omega 3 \mathrm{D}$ rats given access to the $\omega 3$-enriched diet $(0.91 \pm 0.08 ; n=12)$ than in the control animals exposed to the standard diet $(0.36 \pm 0.01 ; n=11)$. It should be underlined, that none of these ratios differed significantly in the $\omega 3 \mathrm{D}$ rats exposed for 2 weeks versus 4-5 weeks to the $\omega 3$-enriched diet, and in the control animals examined 139 versus 264 days after birth. Except in the case of the $\mathrm{C} 20: 5 \omega 3 / \mathrm{C} 18: 3 \omega 3$ ratio, which yielded a higher value $(\mathrm{p}<0.001)$ in the control animals than in the $\omega 3 \mathrm{D}$ rats both exposed to the flaxseed oil-enriched diet, the other two ratios between long-chain polyunsaturated $\omega 3$ fatty acids, i.e. the $\mathrm{C} 22: 6 \omega 3 / \mathrm{C} 20: 5 \omega 3$ and $\mathrm{C} 22: 5 \omega 3 / \mathrm{C} 22: 6 \omega 3$ ratios, failed to differ significantly ( $p>0.4$ or more) in these two groups of rats.

Long-chain polyunsaturated $\omega 6$ fatty acids. The relative weight content of $\mathrm{C} 18: 2 \omega 6$ in liver triglycerides was lower in $\omega 3 \mathrm{D}$ rats than in control animals (Table XI). Such was also the case for $\mathrm{C} 20: 3 \omega 6$ after 7 months dietary $\omega 3$ deprivation and for C20:4 $\omega 6$ after 3 months of dietary $\omega 3$ deprivation. Comparable results were recorded in control and $\omega 3 \mathrm{D}$ rats in the case of $\mathrm{C} 20: 2 \omega 6$ and $\mathrm{C} 22: 4 \omega 6$. The relative weight content of $\mathrm{C} 18: 3 \omega 6$, however, was higher in $\omega 3 \mathrm{D}$ rats than in control animals, such a difference being most pronounced after 3 months of dietary $\omega 3$ deprivation.

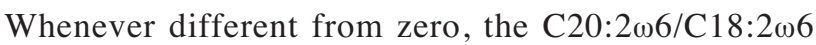
ratio yielded mean values not significantly different in control and $\omega 3 \mathrm{D}$ rats (Table XII). After 7 months of $\omega 3$ deprivation, the $\mathrm{C} 18: 3 \omega 6 / \mathrm{C} 18: 2 \omega 6$ ratio was twice higher in $\omega 3 \mathrm{D}$ rats than in control animals. Even after only 3 months of dietary $\omega 3$ deprivation, such a difference was highly significant $(\mathrm{p}<0.001)$ when all results, including null values, were taken into consideration.

When the control animals were given access to the soybean oil-enriched diet, the $\mathrm{C} 18: 2 \omega 6(\mathrm{p}<0.005)$ and $\mathrm{C} 20: 2 \omega 6$ $(\mathrm{p}<0.02)$ relative content of liver triglycerides became significantly higher than the mean values recorded in the control animals during the first 7 months of the present experiments. The measurements made in the control animals exposed to the flaxseed oil-enriched diet were lower, for all long-chain polyunsaturated $\omega 6$ fatty acids, than the readings recorded in the control animals fed the soybean oil-enriched diet, such a difference only failing to achieve statistical significance $(\mathrm{p}<0.09)$ in the case of $\mathrm{C} 20: 3 \omega 6$. The four ratios between selected long-chain polyunsaturated $\omega 6$ fatty acids listed in Table XII yielded comparable values in the control animals examined before and after exposure to the soybean oil-enriched diet. Exposure of the control animals to the

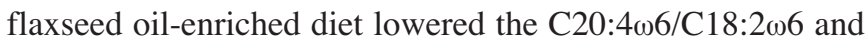
$\mathrm{C} 22: 4 \omega 6 / \mathrm{C} 20: 4 \omega 6$ ratios $(\mathrm{p}<0.02)$ relative to the values found in the control animals fed the soybean oil-enriched diet.

As already mentioned, the sole consistent differences between control and $\omega 3 \mathrm{D}$ rats, in terms of the weight percentage of long-chain polyunsaturated $\omega 6$ fatty acids in liver triglycerides, consisted in a lower amount of C18:2 $\omega 6$, contrasting with a higher amount of C18:3 $\omega 6$ in the $\omega 3 \mathrm{D}$ rats than in the control animals. When the former rats were given access of the $\omega 3$-enriched diet, the relative weight content of C18:2 $\omega 6$ in liver triglycerides remained lower than in control animals. However, the relative weight content of $\mathrm{C} 18: 3 \omega 6$,

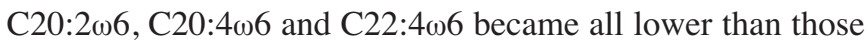
found in the $\omega 3 \mathrm{D}$ rats after 7 months of exposure to the $\omega 3$ deficient diet, such a decrease being highly significant

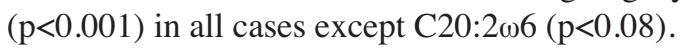

Whenever calculable, the $\mathrm{C} 20: 2 \omega 6 / \mathrm{C} 18: 2 \omega 6$ ratio in liver triglycerides was lower $(\mathrm{p}<0.025)$ in $\omega 3 \mathrm{D}$ rats examined after exposure to the flaxseed oil-enriched diet $(6.74 \pm 0.71 ; n=3)$ than in the $\omega 3 \mathrm{D}$ rats investigated before such an exposure $(9.38 \pm 0.52 ; n=6)$. The elevated $\mathrm{C} 18: 3 \omega 6 / \mathrm{C} 18: 2 \omega 6$ ratio found after 7 months of $\omega 3$ deprivation rapidly returned to a normal value when the $\omega 3 \mathrm{D}$ rats were given access to the $\omega 3$-enriched diet. Likewise, the elevated $\mathrm{C} 20: 4 \omega 6 / \mathrm{C} 18: 2 \omega 6$ ratio found in the $\omega 3 \mathrm{D}$ rats after 7 months of $\omega 3$ deprivation rapidly decreased from $0.153 \pm 0.008$ to $0.095 \pm 0.008$ and $0.071 \pm 0.007$ ( $n=6$ in all cases) when the $\omega 3 \mathrm{D}$ rats were exposed for 2 and 4-5 weeks, respectively, to the $\omega 3$-enriched diet. During the first

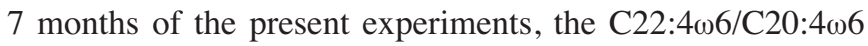
ratio in liver triglycerides failed to differ significantly in the 
Table XIII. Weight percentage of saturated and monodesaturated fatty acids in liver triglycerides.

\begin{tabular}{lccccc}
\hline Rats & $\mathrm{C} 14: 0$ & $\mathrm{C} 16: 0$ & $\mathrm{C} 16: 1 \omega 7$ & $\mathrm{C} 18: 0$ & $\mathrm{C} 18: 1 \omega 9$ \\
\hline $3 \mathrm{mC}$ & $0.3 \pm 0.2(6)$ & $21.4 \pm 1.0(6)$ & $1.9 \pm 0.4(6)$ & $2.1 \pm 0.2(6)$ & $17.7 \pm 0.9(6)$ \\
$3 \mathrm{mD}$ & $1.4 \pm 0.2(6)^{\mathrm{e}}$ & $27.9 \pm 0.5(6)^{\mathrm{f}}$ & $3.5 \pm 0.4(6)^{\mathrm{c}}$ & $2.6 \pm 0.1(6)^{\mathrm{a}}$ & $28.6 \pm 1.1(6)^{\mathrm{f}}$ \\
$7 \mathrm{mC}$ & $0.2 \pm 0.1(5)$ & $24.2 \pm 2.0(5)$ & $2.2 \pm 0.4(5)$ & $2.8 \pm 0.2(5)$ & $17.3 \pm 0.9(5)$ \\
$7 \mathrm{mD}$ & $1.6 \pm 0.1(6)^{\mathrm{f}}$ & $32.1 \pm 2.9(6)^{\mathrm{a}}$ & $3.6 \pm 0.2(5)^{\mathrm{a}}$ & $3.0 \pm 0.3(6)$ & $25.6 \pm 1.0(6)^{\mathrm{f}}$ \\
$7 \mathrm{mC} / 4 \mathrm{wS}$ & $0.7 \pm 0.2(6)$ & $19.1 \pm 0.6(6)$ & $1.1 \pm 0.3(6)$ & $1.9 \pm 0.2(6)$ & $15.2 \pm 0.8(6)$ \\
$7 \mathrm{mC} / 4 \mathrm{wF}$ & $0.5 \pm 0.0(6)$ & $17.6 \pm 0.6(6)$ & $1.1 \pm 0.2(6)$ & $2.6 \pm 0.2(6)^{\mathrm{a}}$ & $15.8 \pm 1.0(6)$ \\
$7 \mathrm{mD} / 2 \mathrm{wF}$ & $0.7 \pm 0.2(6)$ & $21.8 \pm 1.7(6)$ & $2.9 \pm 0.7(6)$ & $2.6 \pm 0.3(6)$ & $22.8 \pm 0.9(6)$ \\
$7 \mathrm{mD} / 4 \mathrm{wF}$ & $0.9 \pm 0.1(6)$ & $22.1 \pm 0.8(6)$ & $3.1 \pm 0.5(6)$ & $2.1 \pm 0.2(6)$ & $22.3 \pm 0.3(6)$ \\
\hline $\mathrm{Sam}$ & & &
\end{tabular}

Same presentation as in Table II.

Table XIV. Ratio between selected saturated and monodesaturated fatty acids in liver triglycerides.

\begin{tabular}{|c|c|c|c|}
\hline Rats & $\mathrm{C} 16: 1 \omega 7 / \mathrm{C} 16: 0(\%)$ & $\mathrm{C} 18: 1 \omega 9 / \mathrm{C} 18: 0$ & $(\mathrm{C} 18: 0+\mathrm{C} 18: 1 \omega 9) /(\mathrm{C} 16: 0+\mathrm{C} 16)$ \\
\hline $3 \mathrm{mC}$ & $8.73 \pm 1.89(6)$ & $8.80 \pm 0.65(6)$ & $0.848 \pm 0.066(6)$ \\
\hline $3 \mathrm{mD}$ & $12.68 \pm 1.44(6)$ & $11.16 \pm 0.92(6)$ & $0.993 \pm 0.023(6)$ \\
\hline $7 \mathrm{mC}$ & $8.62 \pm 1.25(5)$ & $6.26 \pm 0.51(5)$ & $0.780 \pm 0.049(5)$ \\
\hline $7 \mathrm{mD}$ & $11.26 \pm 0.59(6)$ & $8.88 \pm 0.97(6)$ & $0.817 \pm 0.090(6)$ \\
\hline $7 \mathrm{mC} / 4 \mathrm{wS}$ & $5.54 \pm 1.75(6)$ & $8.37 \pm 0.67(6)$ & $0.850 \pm 0.041(6)$ \\
\hline $7 \mathrm{mC} / 4 \mathrm{wF}$ & $5.97 \pm 1.21(6)$ & $6.03 \pm 0.38(6)^{\mathrm{c}}$ & $0.999 \pm 0.084(6)$ \\
\hline $7 \mathrm{mD} / 2 \mathrm{wF}$ & $12.71 \pm 2.02(6)$ & $9.44 \pm 1.22(6)$ & $1.054 \pm 0.063(6)$ \\
\hline $7 \mathrm{mD} / 4 \mathrm{wF}$ & $13.65 \pm 1.68(6)$ & $11.32 \pm 1.40(6)$ & $0.983 \pm 0.056(6)$ \\
\hline
\end{tabular}

Same presentation as in Table II.

control animals and $\omega 3 \mathrm{D}$ rats, with an overall mean value of $0.177 \pm 0.014(\mathrm{n}=20)$. Even if one ignores the fact that such a ratio yielded null values in 9 out of the $12 \omega 3 \mathrm{D}$ rats given access to the $\omega 3$-enriched diet, the mean value recorded in the other 3 rats $(0.094 \pm 0.015)$ remained significantly lower $(\mathrm{p}<0.02)$ than that recorded in the $\omega 3 \mathrm{D}$ rats examined after 7 months exposure to the $\omega 3$-deficient diet $(0.166 \pm 0.013$; $\mathrm{n}=6)$.

Saturated and monodesaturated fatty acids. Detectable amounts of C12:0 in liver triglycerides were only found in five 264-day-old control rats, yielding a mean weight percentage of $0.4 \pm 0.1 \%(n=5)$.

The mean values for the weight percentages of C14:0,

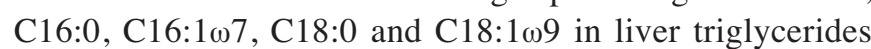
were always higher in $\omega 3 \mathrm{D}$ rats than in control animals, whether after 3 or 7 months of exposure to their respective diets (Table XIII). Such a difference only failed to achieve statistical significance in one out of ten instances, i.e. in the case of C18:0 in the rats examined 7 months after the onset of the present experiments.

The weight percentage of $\mathrm{C} 14: 0$ was higher $(\mathrm{p}<0.05)$ in the control rats after than before exposure to the soybean oilenriched diet. The four other fatty acids listed in Table XIII yielded lower mean values, however, after than just before exposure to the same diet; they averaged after exposure to this diet $70.5 \pm 5.0 \%(n=24 ; p<0.001)$ of the mean corresponding values $(100.0 \pm 5.3 \% ; n=20)$ recorded in the control animals at the end of the first 7 months of the present experiments. Except for a somewhat higher weight percentage $(\mathrm{p}<0.05)$ of $\mathrm{C} 18: 0$ in the control rats exposed to the flaxseed oil-enriched diet, no other significant difference was found for the relative contribution to liver triglycerides of the five fatty acids listed in Table XIII.

When the $\omega 3 \mathrm{D}$ rats were offered access to the $\omega 3$-enriched diet, the mean weight percentages of C14:0, C16:0, C16:1 107 , $\mathrm{C} 18: 0$ and $\mathrm{C} 18: 2 \omega 6$ in liver triglycerides became lower than those recorded in the $\omega 3 \mathrm{D}$ rats after 7 months of exposure to the $\omega 3$-deprived diet. Such a decrease failed to achieve statistical significance in the case of the poorly abundant C16:1 $107(\mathrm{p}>0.3)$ and C18:0 $(\mathrm{p}<0.07)$ fatty acids, whilst being highly significant in the case of C14:0 (p<0.001), C16:0 $(\mathrm{p}<0.001)$ and $\mathrm{C} 18: 1 \omega 9(\mathrm{p}<0.001)$.

Except for the presence of a small amount of C20:1 109 $(0.2 \%)$ in one 264 -day-old $\omega 3 \mathrm{D}$ rat, no C20;0, C20:1 $\omega 9$, $\mathrm{C} 22: 0, \mathrm{C} 22: 1 \omega 9$ and $\mathrm{C} 24: 0$ was detected in the liver triglycerides of control or $\omega 3 \mathrm{D}$ rats up to the age of 264 days. Likewise, among these five saturated and monodesaturated 
fatty acids, only C20:1 109 was detected in one control animal exposed to the soybean oil-enriched diet $(0.2 \%)$ and in $\omega 3 \mathrm{D}$ rats given access to the $\omega 3$-enriched diet, with a mean relative weight content of $0.3 \pm 0.2 \%(n=3)$.

The mean values for both the $\mathrm{C} 16: 1 \omega 7 / \mathrm{C} 16: 0$ and $\mathrm{C} 18: 1 \omega 9 /$ $\mathrm{C} 18: 0$ ratios in liver triglycerides were higher in $\omega 3 \mathrm{D}$ rats than in control animals, whether after 3 or 7 months exposure to their respective diet (Table XIV). Such ratios averaged, in the $\omega 3 \mathrm{D}$ rats, $136.1 \pm 6.3 \%(\mathrm{n}=24 ; \mathrm{p}<0.001)$ of the mean corresponding values found in control animals of the same age $(100.0 \pm 6.8 \% ; n=22)$. When the $\omega 3 \mathrm{D}$ rats were given access to the $\omega 3$-enriched diet, the same ratios failed to return towards control values and, on the contrary, displayed a progressive increase. They indeed averaged, relative to the corresponding mean values found in the $\omega 3 \mathrm{D}$ rats after 7 months of exposure to the $\omega 3$-deprived diet $(100.0 \pm 5.8 \%)$, $109.7 \pm 10.8$ and $124.3 \pm 10.4 \%(n=12$ in all cases $)$ after 2 and 4-5 weeks of exposure to the $\omega 3$-enriched diet, respectively. The progressive increase in these percentages as a function of the length of exposure to the $\omega 3$-enriched diet yielded a correlation coefficient of $0.4366(\mathrm{df}=34 ; \mathrm{p}<0.01)$.

The activity of elongase, as judged from the (C18:0+ $\mathrm{C} 18: 1 \omega 9) /(\mathrm{C} 16: 0+\mathrm{C} 16: 1 \omega 7)$ ratio failed to differ significantly $(\mathrm{p}>0.2)$ in the control animals $(0.817 \pm 0.042 ; \mathrm{n}=11)$ and $\omega 3 \mathrm{D}$ rats $(0.905 \pm 0.052 ; n=12)$, and in the latter rats, failed to change significantly $(\mathrm{p}>0.009)$ during exposure to the $\omega 3$-enriched diet. Likewise, it failed to differ significantly in the control animals before and after exposure to the soybean oil-enriched diet $(\mathrm{p}>0.6)$ and in the control animals fed either the latter diet or the flaxseed oil-enriched diet $(\mathrm{p}>0.1)$.

\section{Discussion}

Igarashi et al (10) recently documented the depletion of liver phospholipid and triacylglycerol in C18:3 $13, \mathrm{C} 20: 5 \omega 3$, $\mathrm{C} 22: 5 \omega 3$ and $\mathrm{C} 22: 6 \omega 3$ prevailing in male rats exposed for 15 weeks after weaning to a diet containing as sole long-chain polyunsaturated $\omega 3$ fatty acid $0.25 \mu \mathrm{mol} / \mathrm{g} \mathrm{C} 18: 3 \omega 3$ (as distinct from $7.8 \mu \mathrm{mol} / \mathrm{g}$ in the control diet). The investigations conducted by these authors differed, however, in several respects from the present study. First, in these investigations, male rats were exposed to the $\omega 3$-depleted diet from weaning onwards, whilst the present study aimed at exploring the consequence of a dietary $\omega 3$ deprivation initiated in female rats already 6-week-old. Second, in the prior investigations, the rats were exposed to diets containing $10 \%$ fat in which C12:0 and C14:0 accounted for $50.7 \pm 2.2 \%$ of total fatty acid content, as distinct from the diets offered during the first seven months of the present experiments containing only $5 \%$ fat in which $\mathrm{C} 12: 0$ and $\mathrm{C} 14: 0$ represented only $0.35 \pm 0.05 \%$ of total fatty acid content. Such differences may well account for the abnormally high liver triacylglycerol content $(64.2 \pm 5.0 \mu \mathrm{mol} / \mathrm{g}$ liver; $\mathrm{n}=10)$ found in the control rats examined by Igarashi et al $(10)$, as compared $(\mathrm{p}<0.001)$ to $10.2 \pm 0.7 \mu \mathrm{mol} / \mathrm{g}(\mathrm{n}=11)$ in the control rats of the present study. Last, the latter situation may well account for the fact that no further significant increase of liver total triacylglycerol content was observed by Igarashi et al (10) in their $\omega 3$-depleted rats, whilst the occurrence of liver steatosis in our $\omega 3$-depleted rats represents an essential feature of the metabolic syndrome in these animals.

The present results document that a dietary deprivation of $\omega 3$ fatty acids for no more than 3 months is sufficient to cause a severe depletion of these fatty acids in both liver phospholipids and triglycerides. This coincided in both lipid fractions with a number of other changes in fatty acid content and pattern.

In the case of liver phospholipids, attention is drawn to the decrease in their total fatty acid content, and perturbations in the content of long-chain polyunsaturated $\omega 6$ fatty acids, saturated and monodesaturated fatty acids and precursors of nervonic acid. The relative weight contents of $\mathrm{C} 18: 2 \omega 6$, $\mathrm{C} 20: 2 \omega 6$ and $\mathrm{C} 20: 3 \omega 6$ were indeed lower and those of $\mathrm{C} 18: 3 \omega 6, \mathrm{C} 20: 4 \omega 6, \mathrm{C} 22: 4 \omega 6$ and $\mathrm{C} 22: 5 \omega 6$ higher in the $\omega 3 \mathrm{D}$ rats than in control animals. The activity of $\Delta 6$-desaturase

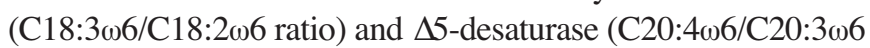
ratio) and $\Delta 9$-desaturase (C16:1 $1 / \mathrm{C} 16: 0$ ratio) appeared also increased in the $\omega 3 \mathrm{D}$ rats. Likewise, the weight contents of

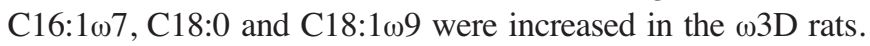

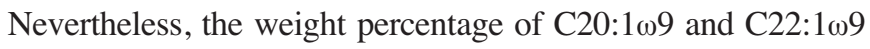
in liver phospholipids only represented in the $\omega 3 \mathrm{D}$ rats about half of the corresponding control values. The postulated increase in $\Delta 5$-desaturase and $\Delta 6$-desaturase liver activity is in agreement with the increased mRNA levels and increased microsomal activities of these enzymes observed by Igarashi et al (11) in the liver of rats exposed to an w3-deficient diet for 15 weeks after weaning. These authors also reported increased mRNA and activity levels of elongase 2 and 5 in the same $\omega 3$-depleted rats. These findings coincide with the increased $C 22: 4 \omega 6 / C 20: 4 \omega 6$ ratio here found in the liver phospholipids of $\omega 3$-depleted rats.

Despite a normal protein content, the total fatty acid and glycerol content of triglycerides were increased in the $\omega 3 \mathrm{D}$ rats. The relative weight content of C18:2 $\omega 6$ in liver

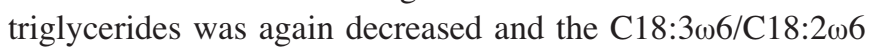
ratio increased, as already noted in liver phospholipids. Likewise, as also observed in phospholipids, the relative weight content of most saturated (C14:0, C16:0) and monodesaturated $(\mathrm{C} 16: 1 \omega 7, \mathrm{C} 18: 1 \omega 9)$ fatty acids, as well as the C16:1 $1 / \mathrm{C} 16: 0$ and $\mathrm{C} 18: 1 \omega 9 / \mathrm{C} 18: 0$ ratios in liver triglycerides, were all increased in the $\omega 3 \mathrm{D}$ rats.

All these features duplicate those found in second generation $\omega 3 \mathrm{D}$ rats $(3,12,13)$. They suggest, therefore, that the present experimental device is appropriate to assess the metabolic consequences of a depletion in $\omega 3$ fatty acids, with emphasis on the development of liver steatosis.

A more nuanced situation prevailed when the $\omega 3 \mathrm{D}$ rats were exposed to an $\omega 3$-enriched diet.

On one hand, when the $\omega 3 \mathrm{D}$ rats were exposed to the flaxseed oil-enriched diet, several hepatic variables moved towards or even beyond control values. In the $\omega 3 \mathrm{D}$ rats, the increase in the liver phospholipid content provoked by the exposure to this $\omega 3$-rich diet was much lower for C20:5 33 than C22:6w3. Such a preferential enrichment of liver phospholipids in $\mathrm{C} 22: 6 \omega 3$ relative to $\mathrm{C} 20: 5 \omega 3$ was recently also observed in $\omega 3 \mathrm{D}$ rats (2nd generation) injected intravenously $60 \mathrm{~min}$ before sacrifice with a novel medium-chain triglyceride:fish oil emulsion containing equal amounts of 


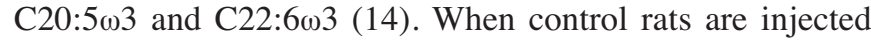
with the same emulsion, the liver phospholipid content of $\mathrm{C} 20: 5 \omega 3$ is also significantly increased, whilst such is no more the case for the $\mathrm{C} 22: 6 \mathrm{\omega} 3$ content of liver phospholipids (3). Likewise, in the present study, the C22:6w3 content of liver phospholipids failed to change significantly in the control animals during exposure to the flaxseed oil-enriched diet, in sharp contrast to the finding made, under the same experimental conditions, in $\omega 3 \mathrm{D}$ rats. These converging observations are compatible with the view that the stepwise conversion of $\mathrm{C} 20: 5 \omega 3$ to $\mathrm{C} 22: 6 \omega 3$ is more efficient in $\omega 3 \mathrm{D}$ rats than in control animals. The $\mathrm{C} 22: 5 \omega 3 / \mathrm{C} 22: 6 \omega 3$ ratio also became higher than that found in the control animals. This coincided with restoration of a normal total fatty acid content of liver phospholipids, a rise of the C18:2 $\omega 6$ relative weight

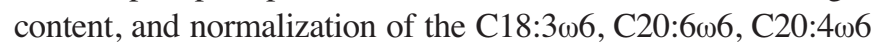
and $\mathrm{C} 22: 4 \omega 6$ phospholipid content, as well as most ratios between selected long-chain polyunsaturated $\omega 6$ fatty acids. Likewise, the weight percentage of most saturated and monodesaturated fatty acids, including precursors or nervonic acid, in liver phospholipids moved back towards control values. In the liver triglycerides, the weight percentage of long-chain polyunsaturated $\omega 3$ fatty acids also reached normal or higher than normal values, except once again in the case of $\mathrm{C} 22: 6 \omega 3$. Nevertheless, significant differences between control animals and $\omega 3 \mathrm{D}$ rats exposed to the flaxseed oil-enriched diet were encountered in the case of several ratios between selected $\omega 3$ fatty acids in liver triglycerides. In these triglycerides, like in phospholipids, the relative weight content of C14:0, C16:0 and $\mathrm{C} 18: 1 \omega 9$ moved towards normal values when the $\omega 3 \mathrm{D}$ rats were exposed to the $\omega 3$-enriched diet.

On the other hand, however, under the same experimental conditions, the $(\mathrm{C} 18: 0 / \mathrm{C} 18: 1 \omega 9) /(\mathrm{C} 16: 0+\mathrm{C} 16: 1 \omega 7)$ ratio in liver phospholipids, which was higher in $\omega 3 \mathrm{D}$ rats than in control animals, was further increased in the $\omega 3 \mathrm{D}$ rats exposed to the flaxseed oil-enriched diet. More importantly, the total fatty acid content of liver triglycerides, which was also abnormally high in the $\omega 3 \mathrm{D}$ rats, was also further increased when the latter rats were given access to the $\omega 3$-enriched diet. Thus, at variance with the situation found in secondgeneration $\omega 3$-depleted rats examined $60 \mathrm{~min}$ after the intravenous injection of a medium-chain triglyceride:fish oil emulsion $(3,12)$, the dietary supply of $\omega 3$ fatty acids to the $\omega 3 \mathrm{D}$ rats failed, in the present experiments, to correct liver steatosis and, on the contrary, caused a further increase in liver triacylglycerol content.

Two factors may well account for the latter unexpected finding.

First, it may be attributable, in part at least, to the fact that the total triglyceride content of the flaxseed oil-enriched diet was twice higher than that of the $\omega 3$-deprived diet offered to the $\omega 3 \mathrm{D}$ rats during the first 7 months of the present experiments. This proposal is consistent with the finding that, in the control rats, exposure to either the soybean or flaxseed oil-enriched diets, which both also contained an amount of triglycerides twice higher than the control diet offered to the control rats during the first 7 months of the present experiments, also increased the liver triglyceride content well beyond the modest rise that could, otherwise, be expected, from the progressive ageing of these animals. In the case of the soybean oil-enriched diet, such an increase could not be attributed to any enrichment of either liver phospholipids or triglycerides in long-chain polyunsaturated $\omega 3$ fatty acids.

Second, the $\omega 3 \mathrm{D}$ rats, when exposed to the flaxseed oilenriched diet, display a rapid and dramatic increase in both body weight and parametrial adipose tissue weight, such an increase not being observed in the control rats exposed to either the soybean or flaxseed oil-enriched diet (15). Hence, an increase in food intake, as conceivably attributable to the supply of $\omega 3$ fatty acids to the $\omega 3 \mathrm{D}$ rats (16-18), may also participate in the aggravation of liver steatosis in these rats.

Considering these two converging factors, it may, quite rightly, be objected that the inclusion in the present study of a further group of $\omega 3 \mathrm{D}$ rats eventually exposed to either the control diet, i.e. that containing only $5 \%$ (wt/wt) of soybean oil, or to a diet only containing $5 \%$ of flaxseed oil, would have been desirable.

In conclusion, the present experiments documents that a dietary deprivation of $\omega 3$ fatty acids for a few months is sufficient to duplicate the changes in the fatty acid content and pattern of liver phospholipids and triglycerides otherwise found in second generation $\omega 3$-depleted rats. The present procedure may thus be recommended as a more simple and realistic approach to explore the metabolic and functional consequences of such a depletion. Our findings draw attention, however, to the idea that in order to correct both the depletion in $\omega 3$ fatty acids and its undesirable consequences, such as liver steatosis, it may be necessary to combine the dietary supply of long-chain polyunsaturated $\omega 3$ fatty acids with a suitable control of food intake, in both qualitative and quantitative terms.

\section{Acknowledgments}

This study was supported by a grant from the Belgian Foundation for Scientific Medical Research (3.4574.07), and by Convention 5459 (Project WALNUT-20) from the Région Wallonne (Namur, Belgium). We are grateful to A. Chwalik, A. Dufour and E. Hupkens for technical assistance and C. Demesmaeker for secretarial help.

\section{References}

1. Armitage JA, Pearce AD, Sinclair AJ, Vingrys AJ, Weisinger RS and Weisinger HS: Increased blood pressure later in life may be associated with perinatal n-3 fatty acid deficiency. Lipids 38 : 459-464, 2003.

2. Cancelas J, Prieto PG, Villanueva-Peñacarrillo ML, Zhang Y, Portois L, Sener A, Carpentier YA, Valverde I and Malaisse WJ: Glucose intolerance associated to insulin resistance and increased insulin secretion in rats depleted in long-chain polyunsaturated $\omega 3$ fatty acids. Horm Metab Res 39: 823-825, 2007.

3. Carpentier YA, Peltier S, Portois L, Sebedio JL, Leverve X and Malaisse WJ: Rapid reduction of liver steatosis in $\omega 3$-depleted rats injected with a novel lipid emulsion. Horm Metab Res 40: 875-879, 2008.

4. Oguzhan B, Sancho V, Acitores A, Villanueva-Peñacarrillo ML, Portois L, Chardigny J-M, Sener A, Carpentier YA and Malaisse WJ: Alteration of adipocyte metabolism in $\omega 3$ fatty acid-depleted rats. Horm Metab Res 38: 789-798, 2006.

5. Oguzhan B, Zhang Y, Louchami K, Courtois P, Portois L, Chardigny J-M, Malaisse WJ, Carpentier YA and Sener A: Pancreatic islet function in $\omega 3$ fatty acid-depleted rats. Glucose metabolism and nutrient-stimulated insulin release. Endocrine 29: 457-466, 2006. 
6. Peltier S, Malaisse WJ, Portois L, Demaison L, Novel-Chate V, Chardigny J-M, Sebebio JL, Carpentier YA and Leverve XM: Acute in vivo administration of a fish oil-containing emulsion improves post-ischemic cardiac function in n-3-depleted rats. Int J Mol Med 18: 741-749, 2006.

7. Folch J, Lees M and Sloane-Stanley GH: A simple method for the isolation and purification of total lipids from animal tissues. J Biol Chem 226: 497-509, 1957.

8. Dahlan W, Richelle M, Kulapongse S, Rössle C, Deckelbaum RJ and Carpentier YA: Effects of essential fatty acid contents of lipid emulsions on erythrocyte polyunsaturated fatty acid composition in patients on long-term parenteral nutrition. Clin Nutr 11: 262-268, 1992.

9. Lepage G and Roy CC: Direct transesterification of all classes of lipids in a one step reaction. J Lipid Res 27: 114-120, 1986.

10. Igarashi M, DeMar JC, Ma K, Chang L, Bell JM and Rapoport SI: Upregulated liver conversion of $\alpha$-linoleic acid to docosahexaenoic acid in rats on a 15 week n-3 PUFA-deficient diet. J Lipid Res 48: 152-164, 2007.

11. Igarashi M, Ma K, Chang L, Bell JM and Rapoport SI: Dietary n-3 PUFA deprivation for 15 weeks upregulates elongase and desaturase expression in rat liver but not brain. J Lipid Res 48: 2463-2470, 2007.

12. Carpentier YA, Peltier S, Portois L, Sener A and Malaisse WJ: Rapid lipid enrichment in $\omega 3$ fatty acids: Liver data. Int J Mol Med 21: 367-373, 2008.
13. Louchami K, Zhang Y, Oguzhan B, Delporte C, Portois L, Carpentier YA, Genten F, Danguy A, Malaisse WJ and Sener A: Rapid changes in liver lipid composition and pancreatic islet $\mathrm{K}^{+}$ handling and secretory behaviour provoked by the intravenous administration of a medium-chain triglyceride:fish oil emulsion to long-chain polyunsaturated $\omega 3$ fatty acid-depleted rats. Int J Mol Med 18: 1047-1055, 2006.

14. Peltier S, Portois L, Malaisse WJ and Carpentier YA: Preferential enrichment of liver phospholipids in docosahexaenoate relative to eicosapentaenoate in $\omega 3$-depleted rats injected with a medium chain triglyceride:fish oil emulsion. Prostaglandins Leukot Essent Fatty Acids 78: 27-32, 2007

15. Sener A, Zhang Y, Bulur N, Louchami K, Malaisse WJ and Carpentier YA: The metabolic syndrome of $\omega 3$-deficient rats. II. Body weight, adipose tissue mass and glycemic homeostasis. Int J Mol Med 24: 125-129, 2009.

16. Goncalves CG, Ramos EJ, Romanova IV, Suzuki S, Chen C and Meguid MM: Omega-3 fatty acids improve appetite in cancer anorexia, but tumor resecting restores it. Surgery 139: 202-208, 2006.

17. Ramos EJ, Romanova IV, Suzuki S, Chen C, Ugrumov MV, Sato T, Goncalves CG and Meguid MM: Effects of omega-3 fatty acids on orexigenic and anorexigenic modulators at the onset of anorexia. Brain Res 1046: 157-164, 2005.

18. Dunlap S and Heinrichs SC: Neuronal depletion of omega-3 fatty acids induces flax seed dietary self-selection in the rat. Brain Res 1250: 113-119, 2009. 